\title{
1. Corporations and international law
}

\section{STATE RESPONSIBILITY FOR ACTS OF PRIVATE PARTIES UNDER INTERNATIONAL LAW}

In this chapter we shall consider the international law background to the 'governance cap' by analysing the responsibilities under international law of its three participants: Host States where subsidiaries of multinational corporations operate; home States where their parent corporations operate; multinational corporations themselves.

\section{A. Host State Responsibility}

States are the primary bearers of obligations under human rights instruments but will also owe an obligation to exercise due diligence to ensure that those rights are not violated by private parties within their jurisdiction. However, host states are often unwilling or unable to take action against corporate wrongdoers within their jurisdiction, and indeed are themselves often the primary violators of the human rights obligations to which they have acceded.

Article 2 of the International Covenant on Civil and Political Rights (the ICCPR) ${ }^{1}$ requires States Parties 'to respect and to ensure to all individuals within its territory and subject to its jurisdiction the rights recognised in the Covenant'. Article 2(2) provides that States Parties undertake to adopt laws and other measures necessary to give effect to the rights recognised by the ICCPR, and Article 2(3) provides that the States Parties must ensure that persons whose rights have been violated have access to an effective remedy, that access to the effective remedy is determined by competent authorities, and that such remedies are enforced when granted. Similar provisions appear in the other core UN Human Rights Treaties, ${ }^{2}$ and also in regional Human Rights Conventions, such as

1 Opened for signature 19 December 1966, 999 UNTS 171 (entered into force 23 March 1976).

2 Such as the International Covenant on Economic, Social and Cultural Rights (ICESCR), opened for signature 16 December 1966, 999 UNTS 3 
the European Convention on Human Rights, ${ }^{3}$ and the Inter-American Court of Human Rights. ${ }^{4}$ The State obligation of due diligence has also been applied by the African Commission on Human and Peoples Rights, although the African Charter on Human and Peoples' Rights lacks a similar express provision. ${ }^{5}$

A State's obligations under international human rights treaties will extend beyond its territory to any area over which the State exercises effective control. The International Court of Justice (ICJ) has held that Israel owed obligations under the ICCPR, ICESCR and the Convention on the Rights of the Child (CRC), in respect of the Palestinian occupied

(entered into force 3 January 1976). The Committee on Economic, Social and Cultural Rights (CESCR), which monitors its implementation, has stated that the Convention requires States Parties to prevent violations of the Convention's rights to water by private actors. CESCR, Substantive Issues Arising in the Implementation of the International Covenant on Economic, Social and Cultural Rights: General Comment 15: The Right to Water, UN ESCOR, 29th sess, Agenda Item 3, [24], UN Doc E/C.12/2002/11 (2002). Article 1 of the Convention on the Prevention and Punishment of the Crime of Genocide 78 U.N.T.S. 277, December 9, 1948, provides that the Contracting parties undertake to prevent and punish the crime of genocide. In 2007 the ICJ in Bosnia $v$. Serbia-Montenegro found that Serbia had violated its obligation to prevent genocide in relation to the massacres at Srebrenica in 1995 and had violated its obligation to punish genocide by failing to hand over Ratko Mladić, indicted for genocide and complicity in genocide, for trial by the International Criminal Tribunal for the former Yugoslavia.

3 Osman v. UK, [1988] EHRR 101.

4 Velásquez Rodríguez v. Honduras, [1988] Inter-Am Court HR (ser C) No 4. in which the Court held that Honduras incurred responsibility for tolerating disappearances of its citizens at the hands of private citizens. The Court held [172] that a State could be responsible for a human rights violation which was not directly imputable to it, "not because of the act itself, but because of the lack of due diligence to prevent the violation or to respond to it'.

5 Commission Nationale des Droits de l'Homme et des Libertés v. Chad, African Commission, Communication No 74/92 (1995). In 2001 in the 'SERAC' case Nigeria was later found to be in breach of its responsibilities under the Charter by failing to take action against pollution in Ogoniland caused by multinational oil companies operating there, the Commission referencing the decision of the Inter-American Court of Human Rights in Velásquez Rodríguez v. Honduras, ibid. African Commission, Communication No 155/96 (2001) ('SERAC Case'). In December 2012 a similar finding was made against Nigeria by the Court of Justice of the Economic Community of West African States (ECOWAS) in SERAP v. Federal Republic of Nigeria, Judgment $\mathrm{N}^{\circ}$ ECW/CCJ/ JUD/18/12. 
territories ${ }^{6}$, and in Democratic Republic of Congo v. Uganda, it found that Uganda owed obligations under the ICCPR, the CRC and the African Charter on Human and Peoples' Rights (ACHPR) in respect of its actions within the territory of the Democratic Republic of Congo. ${ }^{7}$

\section{B. Home State Responsibility}

Under the system of State responsibility codified by the International Law Commission in the 'Draft Articles on Responsibility of States for Internationally Wrongful Acts', there are four ways in which a State may incur responsibility for breach of an international legal obligation in respect of the actions of private parties. ${ }^{8}$ First, in respect of the acts of private parties that are de facto State organs. ${ }^{9}$ This will be the case when private parties are in a state of complete dependence on a State. Second, in relation to para-statal bodies that exercise elements of State authority, such as private bodies that operate prisons, or the conveying of police powers to private bodies. ${ }^{10}$ The conduct of such bodies must 'concern governmental authority and not other private or commercial activity in

6 Advisory Opinion on the Legal Consequences on the Construction of a Wall in the Occupied Palestinian Territory, (2004) 43 ILM 1009 at [107-113].

7 Armed Activities on the Territory of the Congo (Democratic Republic of the Congo v. Uganda), (Merits) (2006) 45 ILM 271 at [217].

8 Report of the International Law Commission to the General Assembly, 56 UN GAOR Supp. (No. 10) at 59, UN Doc. A/56/10 (2001), available at http://www.un.org/documents/ga/docs/56/a5610.pdf.<accessed 24 March 2015>.

9 Article 4 of the Draft Articles: Conduct of organs of a State:

1. The conduct of any State organ shall be considered an act of that State under international law, whether the organ exercises legislative, executive, judicial or any other functions, whatever position it holds in the organization of the State, and whatever its character as an organ of the central Government or of a territorial unit of the State.

2. An organ includes any person or entity which has that status in accordance with the internal law of the State.

10 Article 5 of the Draft Articles: Conduct of persons or entities exercising elements of governmental authority:

The conduct of a person or entity which is not an organ of the State under article 4 but which is empowered by the law of that State to exercise elements of the governmental authority shall be considered an act of the State under international law, provided the person or entity is acting in that capacity in the particular instance. 
which the entity may engage' 11 for it to be attributable to the State. Third, where the private parties, although not de facto organs of the State, are directed or controlled by a State. ${ }^{12}$ In Nicaragua v. US the ICJ set out a test whereby the US would be responsible if it were proved that it had effective control of the military or paramilitary operations in the course of which the alleged violations were committed. ${ }^{13}$ The test was applied by the ICJ in Bosnia v. Serbia in which it held that the perpetrators of the Srebrenica massacres had not been under the effective control of the FRY as regards the massacres. ${ }^{14}$ Fourth, for knowingly aiding and assisting another State in the commission of an internationally wrongful act for which that State is responsible, where that aid and assistance is given to a corporation participating in a project which will involve the other State in the commission of an internationally wrongful act. ${ }^{15}$

11 Commentary on the Draft Articles, p. 43[5]. The Commentary gives the following example: 'Thus, for example, the conduct of a railway company to which certain police powers have been granted will be regarded as an act of the State under international law if it concerns the exercise of those powers, but not if it concerns other activities (e.g. the sale of tickets or the purchase of rolling stock).'

12 Article 8 of the Draft Articles. Conduct directed or controlled by a State:

"The conduct of a person or group of persons shall be considered an act of a State under international law if the person or group of persons is in fact acting on the instructions of, or under the direction or control of, that State in carrying out the conduct."

13 Nicaragua v. US, 65. Unlike the position under art 4, it was not necessary to show a state of complete dependence on the part of the perpetrators.

14 The ICJ rejected a test of attribution for genocide, deriving from the Judgment of the International Criminal Tribunal for the former Yugoslavia (ICTY) Appeals Chamber in Prosecutor v. Tadić, Case (IT-94-1-A, Judgment, 15 July 1999) whereby responsibility would follow when the perpetrators were under the "overall control" of the State. In Tadic the ICTY was not called upon to rule on questions of State responsibility since its jurisdiction was criminal and extended over persons only and the sole question before it, to which it applied a test of "overall control", was whether the conflict was international.

15 Article 16 of the Draft Articles Aid or assistance in the commission of an internationally wrongful act:

A State which aids or assists another State in the commission of an internationally wrongful act by the latter is internationally responsible for doing so if:

(a) that State does so with knowledge of the circumstances of the internationally wrongful act; and

(b) the act would be internationally wrongful if committed by that State. 
Accordingly, it is highly unlikely that a home State will incur responsibility for the acts of its corporations committed outside its jurisdiction. They will not be in a state of complete dependence of the State, nor will the State be in effective control of them in respect of the violations of international law which they might commit (assuming that corporations can be the subjects of obligations under international law). The only situations where State responsibility might arise would be where (a) the corporation exercises state functions, such as a private company providing security or prison services ${ }^{16}$ or (b) the State has provided financial assistance, through export credit guarantees, to the corporation for a project which will clearly involve the host State in violations of international human rights law. An example might be a development project, such as the building of a dam that will involve the displacement of the local population. ${ }^{17}$

But in all the cases that have given rise to litigation in the US, and the UK, which will be considered later in this book, none of these conditions will apply. There would be no question of State responsibility being incurred in such cases. For instance, the Unocal litigation involved a US parent corporation, through its Bermudan subsidiary corporation, being involved in a project creating a pipeline in Burma where human rights abuses were said to have been committed by the Burmese military in the

The International Law Commission's (ILC) Commentary, p. 66 [1] states that art 16 is engaged:

[w] here a State voluntarily assists or aids another State in carrying out conduct which violates the international obligations of the latter, for example, by knowingly providing an essential facility or financing the activity in question. Other examples include providing means for the closing of an international waterway, facilitating the abduction of persons on foreign soil, or assisting in the destruction of property belonging to nationals of a third country.

16 On this basis, a State may incur responsibility for the acts of private military contractors undertaking combat missions or detention and interrogation for a State in armed conflict, such as the US occupation of Iraq. See, further, Chia Lehnardt, IILJ Working Paper 2007/2 Private Military Companies and State Responsibility. www.iilj.org/publications/documents/2007-2.Lehnardt. web.pdf <accessed 27 April 2015>.

17 Robert McCorquodale and Penelope Simons, 'Responsibility Beyond Borders: State Responsibility for Extraterritorial Violations by Corporations of International Human Rights Law', 70 Modern Law Review 598, 612 (2007) cite the Baku-Tbilisi-Ceyhan and the Chad-Cameroon pipeline projects as instances of where the home State could be found to be aiding and assisting an internationally wrongful act. 
course of providing security for the project. Neither the US parent corporation nor the Bermudan subsidiary was in a state of complete dependence on either the US or Bermuda, nor were the US or Bermuda in any way involved with the violation of international law that took place when the corporations allegedly aided and abetted forced labour by the Burmese military in the course of the construction of the pipeline.

There is also the question of which State is responsible for which corporations. Given the recognition of separate corporate personality in international law in Barcelona Traction ${ }^{18}$ a State would only be responsible for the actions of corporations incorporated within its jurisdiction. So, in the Unocal example, the State that would be potentially responsible for the aiding and abetting of the forced labour by the Burmese military would be the US, the state of incorporation of both the parent corporation and its two subsidiary corporations which were participants in the Yadana pipeline joint venture. A further possibility would be Bermuda, due to the subsequent transfer, in 1999, of ownership of the two subsidiaries to a Bermudan corporation. ${ }^{19}$

Even if the necessary conditions exist for State responsibility in respect of the activities of corporations outside its territory, it is unlikely that any proceedings would be brought against the home State by the host State as the latter would be involved in those violations of human rights within its territory. Although violations of jus cogens norms of international law allow any state to make a claim, ${ }^{20}$ it is difficult to conceive of any third

18 Case Concerning the Barcelona Traction, Light and Power Co Ltd (Second Phase) (Belgium v. Spain), [1970] ICJ Reports 3, 42.

19 At one stage in the tort claims before the California Superior Court the defendant was arguing that Bermudan law should apply.

20 Article 48 of the Draft Articles. The Commentary states, p. 126 [2]:

Article 48 is based on the idea that in case of breaches of specific obligations protecting the collective interests of a group of States or the interests of the international community as a whole, responsibility may be invoked by States which are not themselves injured in the sense of article 42 .

This reflects the statement of the ICJ in Barcelona Traction [33] that:

[a]n essential distinction should be drawn between the obligations of a State towards the international community as a whole, and those arising vis-à-vis another State in the field of diplomatic protection. By their very nature the former are the concern of all States. In view of the importance of the rights involved, all States can be held to have a legal interest in their protection; they are obligations erga omnes.

The ICJ then went on to state, [34]: 'Such obligations derive, for example, in contemporary international law, from the outlawing of acts of aggression, and of 
State taking proceedings against another State in respect of human rights violations with which there is complicity by a corporation. To go back again to the Unocal example, in theory the UK, or Sweden, could have brought proceedings before the ICJ against Burma, the US, or possibly Bermuda but the prospect of this happening is virtually nil.

\section{CORPORATE RESPONSIBILITY UNDER INTERNATIONAL LAW}

The traditional province of international law is the regulation of relations between States and accordingly under international law private persons incur no direct responsibility for human rights violations. Such violations fall to be dealt with by their State under national law in accordance with the State's commitments under international law. In his report to the UN Human Rights Council of 19 February $2007^{21}$ Ruggie reviewed the arguments that international human rights instruments imposed direct legal obligations on corporation but merely lacked direct accountability mechanisms, a view propounded by the United Nations Sub-Commission on the Promotion and Protection of Human Rights which underpinned the Draft Norms for Transnational Corporations. He concluded that there was no evidence for such direct corporate legal responsibility in sources such as: the International Bill of Human Rights, the Universal Declaration of Human Rights and the two Covenants (ICESCR and ICCPR) the other core UN human rights treaties and the International Labour Organization (ILO) core conventions. ${ }^{22}$

The preamble to the Universal Declaration of Human Rights proclaims that 'every individual and every organ of society ... shall strive by teaching and education to promote respect for these rights and freedoms and by progressive measures, national and international, to secure their universal and effective recognition and observance'. ${ }^{23}$ The words 'every individual and every organ of society' would suggest that the Universal

genocide, as also from the principles and rules concerning the basic rights of human person, including protection from slavery and racial discrimination.'

21 A/HRC/4/35. Chapter III. 'Corporate Responsibility for other human rights violations under international law', [33-44].

22 Ibid., [44].

23 Adopted as General Assembly resolution 217 (III), 10 December 1948. 
Declaration is directed at all humanity. ${ }^{24}$ However, the preamble represents aspirations and moral claims and does not have legally binding effect. Ruggie then went on to note:

Many provisions of the Universal Declaration of Human Rights have entered customary international law. While there is some debate, it is generally agreed that they currently apply only to States (and sometimes individuals) and do not include its preamble. Most of its provisions have also been incorporated in the Covenants and other United Nations human rights treaties. Do these instruments establish direct legal responsibilities for corporations? Several of them include preambular, and therefore non-binding, recognition that individuals have duties to others. But the operational paragraphs do not address the issue explicitly. ${ }^{25}$

Ruggie then noted an ambiguity in the commentaries of the treaty bodies charged with providing authoritative interpretations:

Where the treaty bodies discuss corporate responsibilities, it is unclear whether they regard them as legal in nature. The most recent general comment of the Committee on Economic, Social and Cultural Rights ... on the right to work, for example, recognizes that various private actors 'have responsibilities regarding the realization of the right to work', that private enterprises national and multinational - 'have a particular role to play in job creation, hiring policies and non-discriminatory access to work'. Fn 36[CESCR, general comment No. 18, para. 52. For similar remarks see CESCR, general comments No. 14, para. 42 and 12, para. 20. See also CRC, general comment No. 5, para. 56, which says that the State duty to respect 'extends in practice' to non-State organizations.] But then, in the same comment, the Committee appears to reiterate the traditional view that such enterprises are 'not bound' by the Covenant. Similarly, the most recent general comment of the Human Rights Committee (HRC) concludes that the treaty obligations 'do not ... have direct horizontal effect as a matter of international law' - that is, they take effect as between non-State actors only under domestic law. fn37 [HRC, general comment No. 31, para. 8.]

However, there is one area of international law which does impose direct obligations on individuals and that is with respect to international crimes for which there is universal jurisdiction. This means that a State may try

24 Louis Henkin has famously written, 'Every individual includes juridical persons. Every individual and every organ of society excludes no one, no company, no market, no cyberspace. The Universal Declaration applies to them all.' 'The Universal Declaration at 50 and the Challenge of Global Markets', Brooklyn Journal of International Law, 17 (April 1999), 25.

$25 \mathrm{~A} / \mathrm{HRC} / 4 / 35,[38]$. 
a person within its jurisdiction in respect of certain crimes committed anywhere in the world, irrespective of any connection with that State. Those crimes are: piracy, torture, ${ }^{26}$ hijacking of aircraft, taking of hostages, slave trading, war crimes, ${ }^{27}$ genocide, ${ }^{28}$ crimes against humanity ${ }^{29}$ - and aiding and abetting such crimes. ${ }^{30}$

The last three crimes are crimes for which an individual may be tried by an international tribunal, such as those established at Nuremberg and Tokyo after the Second World War and subsequently in the ICTY, the International Criminal Tribunal for Rwanda (the ICTR), the Special

26 Universal criminal jurisdiction is obligatory for states that are parties of the Convention Against Torture and Other Cruel, Inhuman or Degrading Treatment or Punishment, UNGA Res. 39/46, 39 UN GAOR Supp. (No. 51), UN Doc. A/39/51 (1984), art 5(2) and is permitted generally under customary international law, see Prosecutor v. Furundzija, IT-95-17/1-T, at II 156 (Dec. 10, 1998), reprinted in 38 ILM 317 (1999).

27 Universal criminal jurisdiction is mandatory for States Parties in respect of grave breaches of the four Geneva Conventions, set out in a 8(2)(a) of the Rome Statute but is not yet established as regards the crimes set out in art 8(2)(b) of the Rome Statute.

28 Although art 6 of the Convention on the Prevention and Punishment of the Crime of Genocide 78 UNTS 277, December 9, 1948 does not provide for universal jurisdiction, it is accepted under customary international law. Prosecutor v. Ntuyahaga, ICTR-90-40-T (Mar. 18, 1999); Prosecutor v. Tadić, IT-94-1AR72, at II 62 (Oct. 2, 1995). This rule is confirmed by State practice. See, e.g., Attorney Gen'l of Israel v. Eichmann, 36 ILR 277, 303-4 (Isr S Ct, 1962); Demjanjuk v. Petrovsky, 776 F.2d 571, 582-3 (6 th Cir. 1985), cert. denied, 475 US 1016 (1986); Prosecutor v. Jorgic, Bundesverfassungsgericht (German Federal Constitutional Court), 2 BvR 1290/99 (Decision of December 12, 2000), reprinted in Neue Juristische Wochenschrift 1848, 1852 (2001).

29 Universal criminal jurisdiction exists over crimes against humanity that were recognized in art 6(2)(c) of the Nuremberg Charter of the International Military Tribunal, 8 UNTS 279, August 8, 1945, including murder, extermination, enslavement, deportation, and other inhumane acts, but is not yet established as regards the new elements of the crime listed in art 7 of the Rome Statute which includes the crimes of apartheid and forcible transfer of populations.

30 The existence of universal criminal jurisdiction was confirmed in the Joint Separate Opinion of Judges Higgins, Kooijmans and Buergenthal in the Case Concerning the Arrest Warrant of 11 April 2000 (Democratic Republic of the Congo v. Belgium), February 14, 2002, [52-65]. 
Court for Sierra Leone (the SCSL). ${ }^{31}$ The 1998 Rome Statute establishing the International Criminal Court (ICC) provides for criminal proceedings to be brought in respect of these three crimes when committed after 1 July 2002. ${ }^{32}$ The Court does not have universal jurisdiction and may only exercise jurisdiction if: the accused is a national of a State Party or a State otherwise accepting the jurisdiction of the Court; the crime took place on the territory of a State Party or a State otherwise accepting the jurisdiction of the Court; or the UN Security Council has referred the situation to the Prosecutor, irrespective of the nationality of the accused or the location of the crime. The principle of complementarity means that the Court will only prosecute an individual if States are unwilling or unable to prosecute..$^{33}$ To this end, States that have ratified the Rome Statute should introduce national legislation to enable them to prosecute the three Rome Statute offences in their national courts. ${ }^{34}$ Currently 65 of the 122 State Parties have introduced such legislation.

\section{A. The Content of the Three Core International Crimes}

\section{Genocide}

In 1948 the UN adopted the Convention on the Prevention and Punishment of the Crime of Genocide. Article 2 defines genocide as:

any of the following acts committed with intent to destroy, in whole or in part, a national, ethnical, racial or religious group, as such:

31 The SCSL is a hybrid court established jointly by agreement between the UN and the government of Sierra Leone. In contrast, the ICTY and ICTR, were established as subsidiary organs of the UN by the Security Council acting pursuant to its Chapter VII powers.

32 Article 5 of the Rome Statute also provides for the ICC to have jurisdiction over the crime of aggression but only 'once a provision is adopted in accordance with articles 121 and 123 defining the crime and setting out the conditions under which the Court shall exercise jurisdiction with respect to this crime.' The 2010 Kampala amendments introduced a new art 8bis on the crime of aggression which has been ratified by 13 states of which four have implemented it into their national legislation. The ICC will not be able to exercise its jurisdiction over the crime of aggression until: at least 30 States Parties have ratified or accepted the amendments; and a decision is taken by two-thirds of States Parties to activate the jurisdiction at any time after 1 January 2017.

33 Article 17 requires the ICC to defer to investigations and prosecutions carried out genuinely by a 'State'.

34 Pursuant to their obligation under art 86 to co-operate with the ICC. 
(a) Killing members of the group;

(b) Causing serious bodily or mental harm to members of the group;

(c) Deliberately inflicting on the group conditions of life calculated to bring about its physical destruction in whole or in part;

(d) Imposing measures intended to prevent births within the group;

(e) Forcibly transferring children of the group to another group.

The crime requires a specific intent whereby the designated acts must be done "with intent to destroy, in whole or in part, a national, ethnical, racial or religious group, as such.' 35 Article 3 provides that the 'following acts shall be punishable':

(a) Genocide;

(b) Conspiracy to commit genocide;

(c) Direct and public incitement to commit genocide;

(d) Attempt to commit genocide;

(e) Complicity in genocide.

The UN Security Council has adopted the 1948 Convention's definitions of genocide in the Statutes for the International Criminal Tribunals for the Former Yugoslavia and Rwanda. In addition, the 1998 Rome Statute for the International Criminal Court also adopts the Convention's definitions.

\section{Crimes against humanity}

Crimes against humanity are not the subject of any convention. The first use of the phrase 'crimes against humanity' was in 1915 when the governments of Great Britain, France and Russia employed it in condemning the Turkish government for the alleged massacres of the Armenians. The first prosecutions for crimes against humanity took place

35 Prosecutor v. Akayesu, Case No. ICTR-96-4-T (Trial Chamber), September 2, 1998, para 498, 517-22: 'Genocide is distinct from other crimes insomuch as it embodies a special intent or dolus specialis. Special intent of a crime is the specific intention, required as a constitutive element of the crime, which demands that the perpetrator clearly seeks to produce the act charged. Thus, the special intent in the crime of genocide lies in 'the intent to destroy, in whole or in part, a national, ethnical, racial or religious group.' Where the charge is complicity in genocide, the mens rea element requires that the accused shared the specific genocidal intent of the primary perpetrator, whereas if the charge is of aiding and abetting genocide the mens rea element requires only that the accused knew of the specific genocidal intent of the primary perpetrator. Akayesu, Prosecutor v. Krstic, ICTY Case No: IT-98-33-A 19 April 2004. 
in 1945 at Nuremberg before the International Military Tribunal (IMT) whose charter defined crimes against humanity as:

murder, extermination, enslavement, deportation, and other inhumane acts committed against any civilian population, before or during the war, or prosecutions on political, racial or religious grounds in execution or in connection with any crime within the jurisdiction of the Tribunal, whether or not in violation of the domestic law of the country where perpetrated.

The same definition was used in the Tokyo Charter of 1946, establishing the International Military Tribunal for the Far East. In 1993 the UN Security Council established the ICTY. Article 5 of the statute establishing the tribunal provides:

The International Tribunal shall have the power to prosecute persons responsible for the following crimes when committed in armed conflict, whether international or internal in character, and directed against any civilian population:

(a) Murder;

(b) Extermination;

(c) Enslavement;

(d) Deportation;

(e) Imprisonment;

(f) Torture;

(g) Rape;

(h) Persecutions on political, racial and religious grounds;

(i) Other inhumane acts.

The list of criminal acts used in Nuremberg was here expanded to include imprisonment, torture and rape. The link with armed conflict was retained. In 1994, the UN Security Council established the ICTR. Article 3 of the ICTR Statute dropped the linkage between crimes against humanity and armed conflict provided that the inhumane acts must be part of a 'systematic or widespread attack against any civilian population on national, political, ethnic, racial or religious grounds'.

The Rome Statute provides for crimes against humanity in Article 7 which adds to the definition of crimes against humanity in the ICTY and ICTR statutes and removes any link to armed conflicts and to the requirement in the ICTR statute that that the attack was carried out 'on national, political, ethnic, racial or religious grounds'. Article 7 defines crimes against humanity as follows: 
For the purpose of this Statute, 'crime against humanity' means any of the following acts when committed as part of a widespread or systematic attack directed against any civilian population, with knowledge of the attack:

(a) Murder;

(b) Extermination;

(c) Enslavement;

(d) Deportation or forcible transfer of population;

(e) Imprisonment or other severe deprivation of physical liberty in violation of fundamental rules of international law;

(f) Torture;

(g) Rape, sexual slavery, enforced prostitution, forced pregnancy, enforced sterilisation, or any other form of sexual violence of comparable gravity;

(h) Persecution against any identifiable group or collectivity on political, racial, national, ethnic, cultural, religious, gender as defined in paragraph 3 , or other grounds that are universally recognised as impermissible under international law, in connection with any act referred to in this paragraph or any crime within the jurisdiction of the Court;

(i) Enforced disappearance of persons;

(j) The crime of apartheid;

(k) Other inhumane acts of a similar character intentionally causing great suffering, or serious injury to body or to mental or physical health.

Article 7(2)(a) provides: 'For the purpose of paragraph 1: 'Attack directed against any civilian population' means a course of conduct involving the multiple commission of acts referred to in paragraph 1 against any civilian population, pursuant to or in furtherance of a State or organizational policy to commit such attack;'. The reference here to the 'State or organizational policy' might suggest that the offence of crimes against humanity may be committed only by State actors, although non-State actors could incur liability for aiding and abetting the crime. However, on three occasions the ICC Pre-Trial Chamber has held that it has jurisdiction over crimes by non-State actors ${ }^{36}$ arising out of the violence that followed the contested results of Kenya's presidential election of 27 December 2007.37

36 The allegations were that a political party had used a criminal organization to attack rival supporters, with the passive complicity of the police. The violence saw over 1,000 murders and numerous rapes.

37 Situation in the Republic of Kenya, Case No. ICC-01/09, Decision Pursuant to Article 15 of the Rome Statute on the Authorization of an Investigation into the Situation in the Republic of Kenya (Mar. 31, 2010), http://www.icccpi. int/iccdocs/doc/doc854562.pdf. The same finding was made in two subsequent decisions authorising joint summonses for the appearances of various Kenyan citizens, including the President, Uhuru Kenyatta. In all three 


\section{War crimes}

These include: (i) grave breaches of the four Geneva Conventions of 12 August $1949^{38}$ and their Additional Protocol I; (ii) other serious violations of international humanitarian law committed during an international armed conflict; ${ }^{39}$ (iii) serious violations of the laws of war applicable in non-international armed conflicts. ${ }^{40}$ Article 8(2)(a) of the Rome Statute covers heading (i). Article 8(2)(b) covers heading (ii) and paragraph (c) cover heading (iii). Paragraph (e) covers other serious violations of international humanitarian law committed during a noninternational armed conflict. With regard to these last two headings, paragraphs (d) and (f) provide that they apply:

[t]o armed conflicts not of an international character and thus does not apply to situations of internal disturbances and tensions, such as riots, isolated and sporadic acts of violence or other acts of a similar nature. It applies to armed conflicts that take place in the territory of a State when there is protracted armed conflict between governmental authorities and organized armed groups or between such groups.

decisions Judge Hans-Peter Kaul dissented on the grounds that the crime required that the group committing the widespread and systematic attack on civilians had certain State-like characteristics. See, further, Charles Chernor Jalloh 'What Makes a Crime against Humanity?' 28 Am. U. Int'l L. Rev. 381 (2013).

381949 Geneva Convention (I) for the Amelioration of the Condition of the Wounded and Sick in Armed Forces in the Field; 1949 Geneva Convention (II) for the Amelioration of the Condition of Wounded, Sick and Shipwrecked Members of Armed Forces at Sea; 1949 Geneva Convention (III) relative to the Treatment of Prisoners of War; 1949 Geneva Convention (IV) relative to the Protection of Civilian Persons in Time of War. https://www.icrc.org/eng/ resources/documents/publication/p0173 (accessed 17 December 2014).

39 Based primarily on the 1899 Hague Declaration, the 1907 Regulations annexed to the Hague Convention No. IV, the 1925 Geneva Protocol, the 1954 Hague Convention for the Protection of Cultural Property in the Event of Armed Conflict and its protocols, the 1989 Convention on the Rights of the Child, the 1994 Convention on the Safety of United Nations and Associated Personnel, and the Statute of the International Criminal Tribunal for the former Yugoslavia.

40 Based primarily on art 3 common to the four Geneva Conventions of 1949, their Additional Protocol II of 1977, the 1999 Optional Protocol to the 1954 Hague Convention for the Protection of Cultural Property in the Event of Armed Conflict, the 1989 Convention on the Rights of the Child, the 1994 Convention on the Safety of United Nations and Associated Personnel, the Statutes of the International Criminal Tribunals for Rwanda and the former Yugoslavia, and the Statute of the Special Court for Sierra Leone. 
Three provisions in Article 8 cover economic war crimes, which might be relevant in connection with illegal acquisition of resources in conflict zones. These are Article 8(2)(a)(iv) on the extensive destruction and appropriation of property, Article $8(2)(\mathrm{b})$ (xiii) and (e)(xii) of the ICC Statute on destroying or seizing the enemy's property, and Article $8(2)(\mathrm{b})(\mathrm{xvi})$ and (e)(v) on pillage. In the Nuremberg trials various German industrialists were charged with pillage in cases involving confiscation by large German companies such as IG Farben, Flick and Krupp of property in German occupied territories in Europe. ${ }^{41}$ The crime was committed where the owner of the property was deprived of his property involuntarily and against his will. In internal conflicts, the crime of pillage is likely to be committed only by rebel groups, as the State is presumed to have ownership of natural resources in its territory. ${ }^{42}$

\section{Modes of liability}

As well as those who commit the actual offences, co-perpetrators and aiders and abetters may also incur criminal liability. In Prosecutor $v$. Tadić, the ICTY recognised that co-perpetrators could be held liable as participants in a joint criminal enterprise in three distinct cases, as follows:

First, in cases of co-perpetration, where all participants in the common design possess the same criminal intent to commit a crime (and one or more of them

41 United States v. Krauch et al. (IG Farben Case), Trials of War Criminals Before the Nuremberg Military Tribunals Under Control Council No. 10, Vol. VIII, 1134.

42 See, further, Larissa Van den Herik and Daniëlla Dam, 'Revitalizing the Antique War Crime of Pillage: The Potential and Pitfalls of Using International Criminal Law to Address Illegal Resource Exploitation During Armed Conflict', 22(3) Criminal Law Forum (2011), who conclude:

However, the historic crime of pillage also has serious inherent limits. Pillage, as originally included in the 1907 Hague Regulations and later in the 1949 Geneva Conventions, was not drafted with the phenomenon of illegal exploitation in mind. This plays out most dramatically in the situation of internal armed conflicts. In these situations, pillage appears to target one side of the armed conflict unevenly. In particular under the ICC definition, it might be difficult to address government actors that exploit 'their' natural resources to fund gruesome armed conflicts with the sole aim of clinging to power.

See, too, Professor James Stewart Corporate War Crimes: Prosecuting Pillage of Natural Resources available at http://www.pillageconference.org/publications/ $<$ accessed 7 April 2015>. 
actually perpetrate the crime, with intent). Secondly, in the so-called 'concentration camp' cases, where the requisite mens rea comprises knowledge of the nature of the system of ill-treatment and intent to further the common design of ill-treatment. Such intent may be proved either directly or as a matter of inference from the nature of the accused's authority within the camp or organisational hierarchy. With regard to the third category of cases, ${ }^{43}$ it is appropriate to apply the notion of 'common purpose' only where the following requirements concerning mens rea are fulfilled: (i) the intention to take part in a joint criminal enterprise and to further - individually and jointly - the criminal purposes of that enterprise; and (ii) the foreseeability of the possible commission by other members of the group of offences that do not constitute the object of the common criminal purpose. ${ }^{44}$

Secondary liability may be incurred for aiding and abetting, the actus reus for which was set out by the ICTY Tribunal in Prosecutor $v$. Furundzija as 'practical assistance, encouragement, or moral support which has a substantial effect on the perpetration of the crime' ${ }^{45}$ As regards mens rea, there is some controversy as to whether knowing assistance or purposive assistance is required, with most of the Nuremberg decisions and those of the ICTY and ICTR pointing to the former. In 2013 there were two divergent decisions of international criminal tribunals on this issue. In Prosecutor v. Perišic, ${ }^{46}$ the ICTY held that it had to be established that the defendant's assistance was 'specifically directed' to aiding the commission of the offence, whereas in Prosecutor v. Taylor, ${ }^{47}$ the SCSL Appeals Chamber held that the mens rea of aiding and abetting was knowledge. On 23 January 2014 in Prosecutor v. Nikola Śainović48 the Appeals Chamber of the ICTY concluded that 'specific direction' is not an element of aiding and abetting liability. The mens rea

43 'The third category concerns cases involving a common design to pursue one course of conduct where one of the perpetrators commits an act which, while outside the common design, was nevertheless a natural and foreseeable consequence of the effecting of that common purpose.' [204].

44 Case No.: -94-1-A 15 July 1999 at para 220. Stephen Powles draws attention to the width of the third category of joint criminal enterprise in 'Criminal Liability by Prosecutorial Ingenuity and Judicial Creativity,' 2(2) Journal of International Criminal Justice 606 (2004). See, too, Darryl Robinson, 'The Identity Crisis of International Criminal Law,' 21 Leiden Journal of International Law 925 (2008), available at < http://ssrn.com/abstract=1127851> (accessed 22 July 2010).

45 Case No. IT-95-17/1, Judgment, paras 195-225, 236-40.

46 Case No. IT-04-81-A (ICTY Feb. 28, 2013).

47 SCSL-03-01-A (10766-11114 Sept. 26, 2013).

48 ICTY, Judgment (Appeals Chamber) (Case No. IT-05-87-A), 23 January 2014. 
standard required the accused to be aware of the essential elements of the specific crime committed, including the mental state of the perpetrators.

The Rome Statute of 1998 establishing the ICC would appear to point towards purposive assistance. Article 25(3) provides that a person 'shall be criminally responsible and liable for punishment for a crime' if that person '[f]or the purpose of facilitating the commission of such a crime, aids, abets or otherwise assists in its commission or its attempted commission, including providing the means for its commission' ${ }^{49}$ Article 30(1), though, points towards knowing assistance and states: '[u]nless otherwise provided, a person shall be criminally responsible and liable for punishment for a crime within the jurisdiction of the [c]ourt only if the material elements are committed with intent and knowledge'. Paragraph 2 then provides that a person has intent where: '(a) In relation to conduct, that person means to engage in the conduct; [and] (b) In relation to a consequence, that person means to cause that consequence or is aware that it will occur in the ordinary course of events' (emphasis added). ${ }^{50}$ Article $25(\mathrm{~d})$ deals with co-perpetration as by providing that a person shall be criminally liable if that person:

In any other way contributes to the commission or attempted commission of such a crime by a group of persons acting with a common purpose. Such contribution shall be intentional and shall either: (i) Be made with the aim of furthering the criminal activity or criminal purpose of the group, where such activity or purpose involves the commission of a crime within the jurisdiction of the Court; or (ii) Be made in the knowledge of the intention of the group to commit the crime.

There is no provision for the third category of joint criminal enterprise set out in Tadić by the ICTY.

49 Rome Statute of the International Criminal Court, art 25, July 17, 1998, 2187 UNTS 90. Article 25(3) plays a prominent role in Robert Harris' thriller 'The Ghost' in which the former UK prime minister, Adam Lang, is investigated by the ICC for aiding and abetting crimes against humanity.

50 Paragraph 106 of the Explanatory Notes to the International Criminal Court Act 2001 states, as regards s 66 'Mental Element':

This section reflects Article 30 of the Statute. It provides a general rule that, unless otherwise provided, the necessary mental element of an offence is present if the material elements of genocide, a crime against humanity, a war crime or an offence against the administration of justice are committed with intent and knowledge. 'Intent' and 'knowledge' are explained in subsection (3) [of art. 30]. 


\section{Torture}

Apart from the Rome Statute, torture has been rendered criminal under the UN Convention against Torture 1984 (UNCAT). It is a crime of universal jurisdiction both under the Convention ${ }^{51}$ and under customary international law. Although torture can only be committed by State actors, it would be possible for a non-State actor to incur criminal liability under UNCAT by reason of its complicity and participation in torture. Article 4(1) provides that, 'Each State Party shall ensure that all acts of torture are offences under its criminal law. The same shall apply to an attempt to commit torture and to an act by any person which constitutes complicity or participation in torture' (emphasis added). In the case of the UK this provision has been implemented in a different manner in section 134(2) of the Criminal Justice Act 1988 which provides:

A person not falling within subsection (1) above commits the offence of torture, whatever his nationality, if -

(a) in the United Kingdom or elsewhere he intentionally inflicts severe pain or suffering on another at the instigation or with the consent or acquiescence -

(i) of a public official; or (ii) of a person acting in an official capacity; and

(b) the official or other person is performing or purporting to perform his official duties when he instigates the commission of the offence or consents to or acquiesces in it.

It does not cover acts constituting complicity in torture.

\section{Universal jurisdiction of national courts over international crimes}

The principle of complementarity in the Rome Statute means that the principal avenue for prosecuting international crimes will be before national courts. International law permits, and in some cases obliges, States to prosecute international crimes wherever they are committed and without any link between the offender and the prosecuting State. ${ }^{52}$ This is

51 Article 5(2) requires each State Party to "[t]ake such measures as may be necessary to establish its jurisdiction over such offences in cases where the alleged offender is present in any territory under its jurisdiction and it does not extradite him pursuant to article 8 to any of the States mentioned in paragraph 1 of this article'.

52 States are obliged to prosecute grave breaches of the Geneva Conventions and torture, pursuant to UNCAT, if they are parties to those Conventions, but there is no such obligation in relation to other cases of war crimes or crimes 
universal criminal jurisdiction. The most famous universal jurisdiction statute is Belgium's 1993 Act on the Punishment of Grave Breaches of International Humanitarian Law, amended in 1999. The Act empowered Belgian courts to try cases of war crimes, crimes against humanity and genocide committed by non-Belgians outside Belgium against nonBelgians, without even the presence of the accused in Belgium. Complaints could be filed by private parties and proceeding were brought in relation to events arising out of the genocide in Rwanda, the killing of two Belgian priests in Guatemala, and crimes alleged against the former dictator of Chad, Hissène Habré.

Claims under the Act were also filed against Israel's prime minister, Ariel Sharon, in connection with his role in the Sabra and Shatila massacres of 1982, while Israeli defence minister. Other high-profile claims were filed against former US President George H.W. Bush, in connection with the bombing of Baghdad in the 1991 Gulf War, and in May 2003 a complaint was filed against US General Tommy Franks alleging that he had ordered war crimes during the invasion of Iraq in 2003. The US responded with Defense Secretary Rumsfeld threatening Belgium with the loss of its status as host to the NATO headquarters, and in August 2003 Belgium succumbed to this pressure by amending its law so that the prosecution of international crimes required some connection between the offender and Belgium. The Belgian courts' jurisdiction over international crimes would be limited to situations where: the accused is Belgian or has his primary residence in Belgium or; the victim is Belgian or has lived in Belgium for at least three years at the time the crimes were committed; or a treaty required Belgium to exercise jurisdiction over the case. In addition, the decision to proceed with a complaint now rests exclusively with the state prosecutor, unless the accused is Belgian or has his primary residence in Belgium. Some pre-existing claims, such as those against Hissène Habré, continued but in September 2003 the high-profile claims against US and Israeli officials were all dismissed by the Belgian court of cassation.

A similar process has happened in Spain where its universal jurisdiction law has twice been cut back in similar fashion. ${ }^{53}$ In November

against humanity, although States probably have a right to prosecute such crimes. The Rome Statute per se does not stipulate a direct obligation of States to establish and exercise national jurisdiction for international crimes, although its Preamble states 'Recalling that it is the duty of every State to exercise its criminal jurisdiction over those responsible for international crimes.'

53 Spain has been active in applying its universal jurisdiction law issuing arrest warrants against two former presidents of Guatemala, Rios Montt and 
2009 Spain amended its universal jurisdiction law so that the future scope of universal jurisdiction would be limited to cases in which: (a) the victims are Spanish; (b) the alleged perpetrators are in Spain; or (c) there exists some other clear link to Spanish interests. The ability to investigate allegations of genocide, crimes against humanity and war crimes will be restricted to suspects who are either a Spanish national, a foreigner habitually resident in Spain, or a foreigner who is in Spain and whose extradition has been denied by Spanish authorities. A further amendment in April 2014 meant that with charges of torture and enforced disappearance, the suspect must be a Spanish national, or the victim must be a Spanish national at the time when the crime was committed and whose suspect is present in Spain. Otherwise, the Spanish courts can now prosecute crimes set out under international treaties only when Spain has received and denied an extradition request, in relation to a foreign suspect present in Spain. The new law provides for the closing of existing investigations which do not, retrospectively, satisfy these criteria.

The legislation implementing the Rome Statute in Canada provides for universal jurisdiction. Section 6(1) of the Crimes Against Humanity and War Crimes Act (S.C. 2000, c. 24) provides: 'Every person who, either before or after the coming into force of this section, commits outside Canada (a) genocide, (b) a crime against humanity, or (c) a war crime, is guilty of an indictable offence and may be prosecuted for that offence in accordance with section 8.' Section 8 provides:

A person who is alleged to have committed an offence under section 6 or 7 may be prosecuted for that offence if

(a) at the time the offence is alleged to have been committed

(i) the person was a Canadian citizen or was employed by Canada in a civilian or military capacity,

(ii) the person was a citizen of a state that was engaged in an armed conflict against Canada, or was employed in a civilian or military capacity by such a state,

(iii) the victim of the alleged offence was a Canadian citizen, or

(iv) the victim of the alleged offence was a citizen of a state that was allied with Canada in an armed conflict; or

Oscar Mejia Victores, for genocide, torture and other related crimes. In October 2013, indictments were issues against former Chinese President Hu Jintao, for allegedly committing genocide in Tibet, followed by similar indictments a month later against former Chinese President Jiang Zemin, and former Prime Minister Li Peng. China reacted angrily to these indictments and it is believed that fears of economic reprisals against Spain led to the further curtailment of the law on universal jurisdiction in 2014. 
(b) after the time the offence is alleged to have been committed, the person is present in Canada.

Accordingly, the presence in Canada of the alleged offender is sufficient to ground jurisdiction and on this basis Désiré Munyaneza was prosecuted and convicted for genocide, crimes against humanity and war crimes committed in Rwanda in 1994. These crimes had all been established under customary international law by 1994, notwithstanding that the Rome Statute was only adopted on 17 July $1998 . .^{54}$ On 7 May 2014 the Quebec Court of Appeal confirmed his conviction and life sentence. However, prosecutions in Canada are allowed only with the consent of the Attorney-General of Canada, which prevents the filing of politically embarrassing claims of the types that were made in Belgium under its 1993 universal jurisdiction statute.

Australia also has universal criminal jurisdiction over the three Rome Statute crimes, but, as with Canada, prosecution can only be brought with the consent of, and in the name of, the Attorney-General. ${ }^{55}$ Universal jurisdiction also exists in relation to torture ${ }^{56}$ and slavery ${ }^{57}$ but where the offence occurs wholly outside Australia no proceedings may take place without the consent of the Attorney-General.

In the UK universal jurisdiction exists in respect of three international crimes. First, there is torture committed after 1988 which may be prosecuted irrespective of where it was committed and whether or not there is any connection to the UK by virtue of section 134 of the Criminal Justice Act 1988 which implements Articles 4 and 5 of the 1984 UNCAT. ${ }^{58}$ Second, pursuant to the Taking of Hostages Act 1982, ${ }^{59}$ there

54 Judgment available at http://www.ccij.ca/programs/cases/index.php? WEBYEP_DI=12 <accessed 24 April 2015>.

55 Section 268.121 of the Criminal Code Act 1995.

56 Division 274 of the Criminal Code. Where the offence occurs wholly outside Australia no proceedings may take place without the consent of the Attorney-General.

57 Division 270 of the Criminal Code. Where the offence occurs wholly outside Australia no proceedings may take place without the consent of the Attorney-General.

58 In $R$ v. Bow Street Magistrates; ex parte Pinochet Ugarte (No 3), [2000] $1 \mathrm{AC} 147$ the House of Lords held that Pinochet was not able to claim immunity for crimes committed while he was President of Chile after 29 September 1989 when s 134 of the Criminal Justice Act 1988 brought into force the provisions of the UNCAT, which established universal criminal jurisdiction for torture. In contrast, in 2007 the Paris prosecutor dismissed a criminal complaint brought by the Center for Constitutional Rights against former US Secretary of Defense, 
is hostage-taking committed after 1982. Third, pursuant to the Geneva Conventions Act 1957, there are grave breaches of the Geneva Conventions committed after 1957, but there is no jurisdiction over war crimes committed in internal armed conflicts. Suspects of these crimes can be arrested and prosecuted if they set foot in UK territory, as there is no immunity ratione materiae for former state officials in respect of crimes of universal jurisdiction. This has led to two embarrassing threats to arrest former Israeli officials for war crimes. In 2005 Israeli General Almog was threatened with prosecution for alleged war crimes in the Palestinian territories (an international armed conflict) under the Geneva Conventions Act 1957 after arriving in the UK for a visit and similarly former Israeli foreign minister Tzipi Livni in 2009. Since 2011 the consent of the Director of Public Prosecutions has been necessary before an arrest warrant can be issued for crimes of universal jurisdiction.

The UK courts also have extra-territorial jurisdiction over UK nationals and residents as regards the three crimes which derive from the International Criminal Court Act 2001 Act which implements the 1998 Rome Statute of the ICC. ${ }^{60}$ First, there are war crimes committed in internal armed conflicts after $2001 .^{61}$ Second, there is genocide committed after 2001.62 Third, there are crimes against humanity committed after 2001.63 There is also extra-territorial jurisdiction under the War Crimes Act 1991 in respect of murder committed in Nazi-occupied

Donald Rumsfeld, in relation to alleged authorisation of torture on detainees at Guantanamo Bay and Abu Ghraib, in violation of UNCAT. The grounds for the dismissal were that former heads of state remained immune from prosecution in relation to official acts committed during their time in office. http://ccrjustice.org/ ourcases/current-cases/french-war-crimes-complaint-against-donald-rumsfeld,-etal. accessed 13 December 2014.

59 This implements the 1979 International Convention Against the Taking of Hostages,

60 The Rome Statute came into force on 1 July 2002, after 60 states had ratified it.

61 The 1998 Rome Statute of the ICC places 'serious violations' of art 3, common to the four Geneva Conventions of 1949, on the same legal footing as 'war crimes' in international armed conflicts.

62 The Genocide Act 1969 criminalised genocide committed in the UK, in line with the 1948 Convention on the Prevention and Punishment of the Crimes of Genocide. The Act was repealed by the International Criminal Court Act 2001.

63 Section 70(3) of the Coroners and Justice Act 2001 inserted a new s 65A into the 2001 Act, providing for the retrospective application of the offences of genocide, crimes against humanity and war crimes and related offences to things done on or after 1 January 1991. With crimes against humanity and certain categories of war crimes under art $8(2)(b)$ and (e) of the Rome Statute, this is 
Europe between 1939 and 1945, and under the Slave Trade Act, 1843, which criminalised participation in the slave trade by 'British subjects ... whether within the dominions of the British crown or of any foreign country'.64

In France there is a two-tiered system of universal jurisdiction for international crimes. Until 2010, France only asserted universal jurisdiction over international crimes where an international treaty obligated France to prosecute. This included jurisdiction over torture, pursuant to the 1984 UNCAT. The French courts also have jurisdiction over genocide, crimes against humanity, and war crimes committed in the former Yugoslavia and in Rwanda, or by Rwandan citizens in neighbouring countries, pursuant to France's implementation of United Nations Security Council Resolutions 827 and 955 establishing the ICTY and the ICTR. On August 9, 2010, the French Code of Criminal Procedure was amended to incorporate the Rome Statute and extend the jurisdiction of French courts to include genocide, crimes against humanity, and war crimes committed after that date. There are four differences between the jurisdiction over these crimes and those added in 2010. First, for the former crimes, there would be jurisdiction where the suspect is present in France at the time that a judicial investigation is opened, but for the 2010 crimes there is jurisdiction only where the accused regularly resides in France. Secondly, there is no subsidiarity requirement for torture and enforced disappearance, ${ }^{65}$ whereas there is such a requirement for the 2010 crimes, so that prosecutors, before opening an investigation, must first verify whether any national or international court has asserted jurisdiction over a suspect or has requested their extradition. Third, the courts can exercise jurisdiction over torture, enforced disappearance and crimes committed in the former Yugoslavia and Rwanda even where the crimes were not punishable in those countries at the time they were committed. In contrast, there is a double criminality requirement for the

subject to the requirement that the act constituting the offence amounted to a criminal offence under international law.

64 Section 71 of the Coroners and Justice Act 2009 creates a new offence in England and Wales and Northern Ireland of holding someone in slavery or servitude, or requiring a person to perform forced or compulsory labour. The offence is to be interpreted in accordance with art 4 of the ECHR. This offence and other offences relating to slavery in s 59A of the Sexual Offences Act 2003 and s 4 of the Asylum and Immigration (Treatment of Claimants, etc,) Act 2004 have now been consolidated in the Modern Slavery Act 2015.

65 The French courts defer to the ICTY and ICTR which have primary jurisdiction over crimes committed in the former Yugoslavia and Rwanda. 
2010 international crimes. Fourth, while criminal proceedings for serious offences can normally be initiated by prosecutors or private parties, such as victims and other affected parties, including nongovernmental organizations (NGOs), only the prosecution service may trigger prosecutions for the 2010 international crimes.

Universal jurisdiction provisions also appear in national legislation implementing the Rome Statute in: New Zealand's International Crimes and International Criminal Court Act 2000; Germany's Article 1 of its Code of Crimes Against International Law 2002, 42 ILM (2003) 995; South Africa's South African Implementation of the Rome Statute of the International Criminal Court Act 2002 section 4(3)(c); The Netherlands' International Crimes Act 2003; Ireland's International Criminal Court Act 2006 in respect of war crimes committed in international armed conflicts.

In the US, which has signed, but not ratified, the Rome Statute, universal criminal jurisdiction exists over piracy, genocide, ${ }^{66}$ and torture. There is extra-territorial jurisdiction in respect of war crimes. Section 404 of the Restatement Third provides that there is universal jurisdiction to define and prescribe punishment for certain offences recognised by the community of nations as of universal concern, such as piracy, slave trade, attacks on or hijacking of aircraft, genocide, war crimes, and perhaps certain acts of terrorism.

\section{Sovereign immunity and international crimes}

The immunity ratione personae of serving Heads of State will continue to bar proceedings against such persons in respect of proceedings before national courts in respect of international crimes. In 2002 the ICJ in the Arrest Warrant case held that there was no rule of international law denying immunity to Heads of State in relation to criminal prosecutions before national courts in respect of international crimes. ${ }^{67}$ However, Head of State immunity will not provide a defence where international crimes

66 The 1988 Proxmire Act criminalised genocide only when 'the offense is committed within the United States' or where 'the alleged offender is a national of the United States'. Subsequently the Genocide Accountability Act of 2007, Pub L No. 110-151, 121 Stat 1821 (codified as amended at 18 USC § 1091 (2006 \& Supp. IV 2010)). criminalised genocide outside the US by nonAmericans, provided that they would subsequently be present in the US.

67 Case concerning Arrest Warrant of 1 I April 2000 (Democratic Republic of the Congo v. Belgium), Judgment, ICJ Reports 2002, p. 3 ISSN 0074(February 14, 2002). The case arose out of Belgium's issue of an arrest warrant against the serving Foreign Minister of the Democratic Republic of the Congo in respect of allegations of international crimes committed by him during the genocide in Rwanda. 
are prosecuted before an international tribunal such as the Nuremberg and Tokyo tribunals, the ICC 68 or the SCSL. before which Charles Taylor was prosecuted while still the Head of State of Liberia. On May 31, 2004, the Appeals Chamber of the SCSL ruled unanimously that Charles Taylor did not enjoy any immunity from prosecution by the court although he was the serving Head of State of Liberia at the time criminal proceedings were initiated. ${ }^{69}$ The Appeals Chamber explained the different treatment of sovereign immunity in national and international courts as being due to:

the principle that one sovereign state does not adjudicate on the conduct of another state; the principle of state immunity derives from the equality of sovereign states and therefore has no relevance to international criminal tribunals which are not organs of a state but derive their mandate from the international community. ${ }^{70}$

To date the ICC has issued arrest warrants against three serving Heads of State: Sudan's Omar al Bashir in 2009; Libya's Muammar Gadaffi in 2011; Kenya's Uhuru Kenyatta in April 2011. In October 2014 Kenyatta became the first Head of State to appear before the ICC but due to problems with evidence the prosecution was dropped in December 2014.

However, the practice of national courts in criminal prosecutions for international crimes against former State officials is that such proceedings will not be barred by functional immunity, or immunity ratione materiae, of former State officials. ${ }^{71}$ In $R v$. Bow Street Metropolitan Stipendiary Magistrate and others, ex parte Pinochet Ugarte (Pinochet

68 Pursuant to art 27 of the Rome Statute.

69 Prosecutor v. Charles Ghankay Taylor, Case Number SCSL-2003-01-I, Decision on Immunity from Jurisdiction, 31 May 2004. The motion was heard in the Appeals Chamber by Justices Emmanuel Ayoola, George Gelaga King, and Renate Winter. The Decision is available at http://www.eccc.gov.kh/sites/default/ files/Taylor.pdf accessed 13 December 2014.

70 At [51].

71 See, criminal proceedings for crimes against humanity committed in World War Two brought by Israel against Adolf Eichmann, Attorney General of Israel v. Eichmann, 36 ILR (1962) 5, the numerous proceedings brought in the courts of Belgium and Spain against former heads of state. See, too, Ferrini v. Federal Republic of Germany, 11 March 2004, 128 ILR 659, where the Italian Court of Cassation stated that, in its view, it was 'undisputed' that State officials do not enjoy functional immunity in respect of crimes under international law. This was a civil case concerned with the immunity of the State itself, and the issue of functional immunity was not considered in the subsequent decision of the ICJ to the effect that a State's immunity in civil proceedings persisted, 
(No 3) $)^{72}$ the House of Lords upheld Spain's request for the extradition of the former Chilean dictator, Pinochet, on charges of torture committed during his time as Head of State after 29 September 1989 when torture became a crime in the UK with the implementation of the UNCAT to which both Chile and the UK were parties. Probably the best explanation of the decision is that a grant of immunity ratione materiae would have been inconsistent with those provisions of UNCAT according universal jurisdiction for torture, a crime that can only be committed by state officials. Lord Millett stated:

The offence can be committed only by or at the instigation of or with the consent or acquiescence of a public official or other person acting in an official capacity. The official or governmental nature of the act, which forms the basis of the immunity, is an essential ingredient of the offence. No rational system of criminal justice can allow an immunity which is coextensive with the offence. ${ }^{73}$

Lord Phillips stated the position as regards international crimes in general:

International crimes and extra-territorial jurisdiction in relation to them are both new arrivals in the field of public international law. I do not believe that State immunity ratione materiae can co-exist with them. The exercise of extra-territorial jurisdiction overrides the principle that one State will not intervene in the internal affairs of another. It does so because, where international crime is concerned, that principle cannot prevail ... . Once extra-territorial jurisdiction is established, it makes no sense to exclude from it acts done in an official capacity. ${ }^{74}$

As against these decisions of national courts, there is a dictum in the Arrest Warrant case where the ICJ appears to suggest that immunity ratione materiae would bar the prosecution of officials or former officials for international crimes committed whilst in office. ${ }^{75}$ The Court listed four circumstances in which a criminal prosecution could be made against an incumbent or former Foreign Minister where this immunity would not act as a bar to criminal prosecution. The third of these was the

notwithstanding that the claims made against it involved violations of jus cogens norms of international law.

72 [2000] 1 AC 147.

73 Ibid., p. 277.

74 Ibid., p. 289.

75 Case concerning Arrest Warrant of 1 April 2000 (Democratic Republic of the Congo v. Belgium), note 67 above, p. 3, [6.1]. 
prosecution of a former Foreign Minister in the courts of another State 'in respect of acts committed prior or subsequent to his or her period of office, as well as in respect of acts committed during that period of office in a private capacity'. This suggests that immunity in respect of official acts committed during the Foreign Minister's time in office continues after he or she has stepped down from office. However, the case involved the assertion of a claim to immunity ratione personae and in their joint separate opinion, Judges Higgins, Kooijmans and Buergenthal noted that the current trend of State practice is that former State officials are not covered by immunity ratione materiae when prosecuted in national courts for serious international crimes. ${ }^{76}$ It also seems to be the case that immunity ratione materiae is not available in respect of an international crime committed in the territory of the forum State. ${ }^{77}$

\section{International crimes and corporations}

From Nuremberg onwards international tribunals have only assumed criminal jurisdiction over natural persons. Although the Nuremberg tribunals had the authority to declare an organisation to be criminal, this was with a view towards facilitating the imposition of liability on the individual members of the organisation. The tribunals had no jurisdiction to impose criminal liability on the organisation itself. The position is the same with the ICTY and ICTR which possessed jurisdiction over natural persons, but not over legal persons. ${ }^{78}$ So too with the ICC, where Article 25(1) of the Rome Statute provides: 'The Court shall have jurisdiction over natural persons pursuant to this Statute.'

Notwithstanding this, several States that have implemented the provisions of the Rome Statute into their domestic law do not limit their jurisdiction over the three international crimes to natural persons. In the UK, section 51(1) of the International Crimes Act 2001 provides: 'It is an

76 Ibid., [74] [85].

77 In Pinochet (No 3), note 58 above, Lord Millet said: 'The plea of immunity ratione materiae is not available in respect of an offence committed in the forum state, whether this be England or Spain.', p. 277. In 2009 an Italian court convicted, in absentia, various CIA agents for their abduction of Abu Omar, a suspected terrorist who was then flown to Cairo where he was allegedly tortured. See, too, the extradition from the UK of Khurts Bat, the secretary of the executive office of the Mongolian National Security Office, in relation to charges in Germany relating to the kidnapping in France and forcible transportation to Berlin of a Mongolian national, in Khurts Bat v. Investigating Judge of the German Federal Court, [2011] EWHC 2029 (Admin).

78 Unlike the Nuremberg tribunals, these subsequent tribunals had not been given jurisdiction to declare organisations to be criminal. 
offence against the law of England and Wales for a person to commit genocide, a crime against humanity or a war crime.' Section 52 provides for an offence in relation to conduct ancillary to these crimes. The Schedule to the Interpretation Act 1978 provides that 'person' includes 'a body of persons corporate or unincorporate'. The sections apply to acts committed in England and Wales and accordingly a company could be criminally liable if it committed one of the three Rome Statute crimes within England and Wales. However, for acts outside the UK the sections apply only to acts committed by a UK national, a UK resident or a person subject to UK service jurisdiction. ${ }^{79}$ Accordingly there would be no jurisdiction over a company for an international crime committed outside the UK.

In Australia the three Rome Statute criminal offences were inserted into the Criminal Code as Division 268 by the International Criminal Court (Consequential Amendments) Act 2002 (Cth.). Under the Criminal Code there is a presumption that all offences therein apply equally to bodies corporate as to natural persons. ${ }^{80}$ Division 268 offences fall in the broadest category of jurisdiction under the Criminal Code, Category D, under which anyone, anywhere, regardless of citizenship or residence, can be tried for an offence committed anywhere in the world, without the availability of a foreign law defence. ${ }^{81}$ It would therefore be possible for Australia to prosecute a corporation of any nationality for conduct amounting to a Division 268 offence wherever in the world it is committed.

There is a divergence of approaches in national criminal laws to the attribution of knowledge to companies in offences. In the US the doctrine of respondeat superior is applied whereby a corporation may be held criminally liable for the illegal acts of its directors, officers, employees, and agents, provided that individual's acts were within the scope of his duties and were intended, at least in part, to benefit the corporation. ${ }^{82}$ In

79 Section 67(3) defines a 'person subject to UK Service jurisdiction' by reference to the various Service Discipline Acts.

80 Part 2.5, section 12.1 of the Criminal Code.

81 Section 15.4 describes the extended geographical jurisdiction of Category $\mathrm{D}$ as follows:

'If a law of the Commonwealth provides that this section applies to a particular offence, the offence applies:

(a) whether or not the conduct constituting the alleged offence occurs in Australia; and (b) whether or not a result of the conduct constituting the alleged offence occurs in Australia.'

82 New York Central \& Hudson River Railroad v. US, 212 US 481 (1909). 
the UK liability is incurred due to the knowledge of directors or high level officials constituting the 'directing mind and will' of the company. ${ }^{83}$ A wider test is now applied in relation to corporate manslaughter where the breach which causes the death must be directly attributable to a 'senior management failure'. ${ }^{84}$ In Australia section 12(3) of the Criminal Code Act 1995 provides that, for offences of intention, knowledge or recklessness, the 'fault element must be attributed to a body corporate that expressly, tacitly or impliedly authorised or permitted the commission of the offence'. This can be shown in one of three ways. First, by 'proving that the body corporate's board of directors intentionally, knowingly or recklessly carried out the relevant conduct, or expressly, tacitly or impliedly authorised or permitted the commission of the offence'. Second, by 'proving that a high managerial agent of the body corporate intentionally, knowingly or recklessly engaged in the relevant conduct, or expressly, tacitly or impliedly authorised or permitted the commission of the offence'. Third, through 'proving that a corporate culture existed within the body corporate that directed, encouraged, tolerated or led to non-compliance with the relevant provision; or ... proving that the body corporate failed to create and maintain a corporate culture that required compliance with the relevant provision'. Subparagraph 6 defines 'corporate culture' as an 'attitude, policy, rule, course

83 Tesco v. Nattrass, [1972] AC 153. The principle derives from the principle of attribution in civil cases set out in Lennard's Carrying Co Ltd v. Asiatic Petroleum Co Ltd, [1915] AC 705. With certain regulatory offences attribution may be determined by the construction of a particular statute, irrespective of the 'directing mind' principle, as seen in the approach of the Privy Council in Meridian Global Funds Management Asia Ltd v. Securities Commission [1995] 2 AC 500 (PC) and in $R$ v. British Steel plc, [1995] 1 WLR 1356, regarding offences under The Health and Safety at Work Act 1974.

84 Corporate Manslaughter and Corporate Homicide Act 2007. Section 1(1) provides: 'An organisation to which this section applies is guilty of an offence if the way in which its activities are managed or organised - (a) causes a person's death, and (b) amounts to a gross breach of a relevant duty of care owed by the organisation to the deceased.' Section 1(3) provides: 'An organisation is guilty of an offence under this section only if the way in which its activities are managed or organised by its senior management is a substantial element in the breach referred to in subsection (1).' Under s 1(4)(c) 'senior management' means 'the persons who play significant roles in - (i) the making of decisions about how the whole or a substantial part of its activities are to be managed or organised, or (ii) the actual managing or organising of the whole or a substantial part of those activities'. 
of conduct or practice existing within the body corporate generally or in the part of the body corporate in which the relevant activities takes place'.

\section{Prosecutions of corporations and corporate officials for international crimes before national courts}

Many States have implemented universal jurisdiction provisions under which corporations as well as natural persons can be prosecuted in respect of international crimes. It has been argued that the appropriate focus in closing the governance gap should be on criminal, rather than civil, liability. ${ }^{85}$ However, a survey of criminal proceedings to date against corporations or corporate officers, shows that there have been only a handful of convictions against individuals.

Australia In October 2004, fighting took place at Kilwa, in the Democratic Republic of Congo (DRC), between government and rebel forces who had briefly occupied the town. During the fighting civilians suffered summary executions, arbitrary arrest, rape and torture at the hands of government soldiers. Anvil Mining, which had offices in Australia and Canada, operated a copper mine near Kilwa and it was alleged that it provided planes and vehicles to transport government forces during the fighting. In September 2005, the Australian Federal Police launched an investigation into Anvil's actions in relation to its possible complicity in war crimes and crimes against humanity committed by the Congolese government forces. Anvil always denied any direct involvement in these violations stating that its vehicles had been requisitioned by the Congolese authorities. Criminal proceedings were then brought before a military court in the DRC against 12 individuals, including three Anvil employees, in connection with the events at Kilwa. In June 2007 all the accused were acquitted with the tribunal also stating that Anvil Mining was not guilty, although no charges had been brought against the company. In August 2007 the Australian police closed their criminal investigation into Anvil Mining.

85 Professor James G. Stewart 'The Turn to Corporate Criminal Liability for International Crimes: Transcending the Alien Tort Statute', 47 New York University Journal of International Law and Politics (2014). Professor Stewart is a former appeals counsel for the Prosecutor of the ICTY and presently, a senior legal adviser (part-time) to appellate judges at the Extraordinary Chambers in the Courts of Cambodia. 
Belgium In 2002 a lawsuit was filed by four Burmese refugees, who alleged ‘complicity in crimes against humanity' under Belgium's Universal Jurisdiction Act of June 16, 1993 relative to serious violations of international human rights against Total, its Chairman and the former president of its Burmese affiliate. ${ }^{86} \mathrm{~A}$ claim for compensation for the victims was attached to the criminal proceedings under an action civile. The proceedings were subsequently dismissed by the Cour de Cassation in 2005 , a ruling subsequently confirmed in $2007 .{ }^{87}$

France In 2002 a further suit was filed against Total by eight Burmese nationals alleging Total's 'complicity in unlawful confinement' arising out of their submission to forced labour by the Burmese army on the construction of the Yadana pipeline. In November 2005 Total and the French NGO representing the Burmese nationals agreed a settlement involving the creation of a €5.2-million solidarity fund to compensate the eight plaintiffs as well as any other person who can demonstrate that they suffered a similar experience in the area near the pipeline construction corridor. The fund will also be used to finance humanitarian actions benefiting Myanmar refugees in the region. On March 10, 2006, Nanterre's Tribunal de Grande Instance dismissed the case.

Germany In Germany corporations cannot be held criminally liable but senior managers may incur criminal responsibility. On 25 April 2013, two NGOs filed a criminal complaint in Germany against Olof von Gagern, a senior manager of Danzer Group, a Swiss and German timber manufacturer. The complaint arises out of claims that human rights abuses were committed by Congolese police and military during an attack on the village of Bongulu in northern DRC on 2 May 2011 and that von Gagern aided and abetted these abuses by failing to prevent these crimes from being committed. It is also alleged that the security forces received financial and logistical help from a former subsidiary of Danzer, Siforco. The allegations are denied.

The Netherlands Three criminal proceedings have been brought in relation to alleged commission of international crimes, two against

86 Total was one of the partners in the Yadana project. Attempts to sue it in the US under the Alien Tort Statute failed due to want of jurisdiction.

87 The 1993 Universal Jurisdiction law was repealed by an Act of August 5, 2003. This provided a procedure for terminating certain proceedings that were under way. In June 2006 the Belgian Cour d'Arbitrage annulled this procedure. However, this did not affect the dismissal by the Cour de Cassation in 2005. 
individuals, the other against a company. The first involved criminal proceedings against Frans van Anraat for complicity in genocide and in war crimes. Between 1984 and 1988 he became Saddam Hussein's sole supplier of thiodiglycol, a key component in mustard gas which the Iraqi military used against the Iranian military and civilians in its war with Iraq and also against the Kurds in Northern Iraq. Van Anraat bought the chemical from the US and Japan and then sold it on through a number of different companies located in different countries to Iraq. Van Anraat was charged with complicity in genocide and complicity in war crimes. The District Court of the Hague acquitted him of the former charge of complicity because it could not be proved that he knew of the genocidal intent of the Iraqi regime, but convicted him on the latter charge, applying the international law standard of aiding and abetting. He was sentenced to 15 years' imprisonment, a term subsequently increased to 17 years by the Court of Appeal of the Hague, which applied Dutch domestic criminal law to the issue of complicity. ${ }^{88}$ In 2009, the Supreme Court of the Netherlands upheld Van Anraat's conviction for complicity in war crimes but reduced his sentence by six months, ${ }^{89}$ and in 2010 the European Court of Human Rights rejected Van Anraat's claims challenging the jurisdiction of the Dutch courts and the legal certainty of the criminal acts being prosecuted. ${ }^{90}$ In March 2012, the Dutch Prosecutor applied for the confiscation of Van Anraat's profits, of over 1 million Euros, from his sales of the chemical to Iraq. On 24 April 2013, the District Court of the Hague in the Netherlands ordered Frans van Anraat to pay compensation to 17 victims of chemical weapon attacks on the Kurdish city of Halabja by Saddam Hussein in 1988. On 7 April 2015 the Appeals Court upheld the District Court's verdict. ${ }^{91}$

The second case involved Guus Kouwenhoven who was charged with arms smuggling and war crimes in Liberia in the 1990s. In 2006 he was sentenced to eight years in jail for arms smuggling, but acquitted of war

88 District Court of The Hague, 23 December 2005, Case No. AX6406; Court of Appeal of The Hague, 9 May 2007, Case No. BA6734. Article 48 of the Dutch Penal Code requires that the accused provided the opportunity and/or the means to carry out the attacks described in the charges. According to previous decisions of the Supreme Court of the Netherlands the assistance need not be indispensable and it is enough that the accessory's assistance promoted the offence or made it easier to commit that offence.

89 Dutch Supreme Court, 30 June 2009, Case No. BG4822.

90 Van Anraat v. the Netherlands, Application no. 65389/09, 20 July 2010.

91 http://www.prakkendoliveira.nl/en/news/decision-that-van-anraat-must-paycompensation-to-victims-of-chemical-attacks-in-iraq-confirmed/ <accessed 24 April 2015>. 
crimes charges. ${ }^{92}$ In 2008 the Court of Appeal in the Hague acquitted him of all charges and in 2010 following an appeal by the prosecution to the Supreme Court a retrial was ordered. ${ }^{93}$ In November 2014 the court heard arguments for dismissal in the absence of available witnesses.

The third case involved a complaint filed in March 2010, by an NGO, Al Haq, against Riwal, a Dutch company, for its alleged complicity 'in the commission of war crimes and crimes against humanity ... through its supply of mobile cranes and aerial platforms for the construction of settlements and the Wall in several locations in the Occupied West Bank'. ${ }^{94}$, in violation of the Geneva Conventions and, consequently, the Dutch International Crimes Act (Wet Internationale Misdrijven). In May 2013 the prosecutor decided not to proceed against the crane lessor or its directors as Riwal had ceased working in Israel and the occupied territories and its contribution to the building of the security barrier and settlements had been limited.95 The Dutch government has stated that while such settlements are illegal and it discourages Dutch involvement, the involvement of Dutch companies was not prohibited. ${ }^{96}$

Switzerland Two complaints have been filed against Swiss companies by NGOs. In March 2012, the European Centre for Constitutional Human Rights (ECCHR) and Colombian NGOs filed a criminal complaint with Swiss authorities against Nestlé S.A. and senior managers. They claimed that Nestlé negligently contributed to the 2005 murder of Luciano Romero, a Sinaltrainal trade unionist who worked at a Colombian subsidiary of Nestlé until 2002. In May 2013 Swiss prosecutors announced that they had decided not to prosecute because the case was

92 District Court of The Hague, 7 June 2006, Case No. AY516.

93 Dutch Supreme Court, 20 April 2010, Case No. BK8132.

94 Al Haq, Criminal Complaint Lodged Against Dutch Company for Construction of Settlements and 'The Wall' (Oct. 14, 2010), at http://www.alhaq.org/ advocacy/targets/accountability/71-riwal/472-criminal-com plaint-lodged-againstdutch-company-for-construction-of-settlements-and-the-wall.

95 Openbaar Ministerie, Geen verder onderzoek naar kraanverhuurder (No further testing for crane hire) (May 14, 2013), at http://www.om.nl/algemene_ onderdelen/uitgebreid_zoeken/@160903/verder-onderzoek/.

96 Press Release of the Dutch Government, Questions and Answers, Aanhangsel van de Handelingen, Tweede Kamer der Staten-Generaal (Appendix of Acts, second chamber of the states-general) (Sept. 16, 2013), at https:// zoek.officielebekendmakingen.nl/ah-tk-20122013. 
barred by the statute of limitations. ${ }^{97}$ Since the decision, the NGOs and Romero's wife have appealed the order to the cantonal criminal court, claiming that the prosecutors engaged in improper delay in reviewing the case and that the incorrect statute of limitations was applied. ${ }^{98}$ Romero's widow lodged her own criminal complaint and subsequently appealed against the decision of the Swiss authorities and this appeal was dismissed in December 2013. A further appeal was made before the Swiss Federal Supreme Court based on the grounds that the statute of limitations did not begin to run with the commission of the crime itself and was a continuing offence based on the corporation's failure to take any action to remedy organizational deficiencies within the firm. On 21 July 2014 the Swiss Federal Supreme Court dismissed the appeal and confirmed that time started to run from the murder of Romero and that the case was accordingly statute barred.

A second complaint was filed on 1 November 2013 by a Swiss NGO, TRIAL, against a Swiss gold refinery, Argor-Heraeus SA, in connection with allegations that it had refined gold pillaged by an illegal armed group in the DRC. The Swiss public prosecutor opened a criminal investigation into the complaint but in March 2015 the case was dropped after investigators failed to find any evidence that Argor-Heraeus SA had knowingly dealt with shipments of illegally mined gold.

US In March 2007 Chiquita Brands International Inc. which is incorporated in New Jersey and headquartered in Cincinnati, Ohio, pleaded guilty before the US District Court for the District of Columbia to a count of engaging in transactions with a specially-designated global terrorist right-wing terrorist organisation, the "Autodefensas Unidas de Colombia' (the AUC). The AUC had been designated by the US government as a Foreign Terrorist Organization (FTO) on September 10, 2001, and as a Specially-Designated Global Terrorist (SDGT) on October 31, 2001 which meant that it was a federal crime for a US corporation to provide money to it. Under the terms of the plea agreement, Chiquita received a $\$ 25$ million criminal fine, was required to implement and maintain an effective compliance and ethics programme, and five years' probation. ${ }^{99}$

97 European Coalition for Corporate Justice, Update in the Nestle' Case: Prosecutor Under Court Review (June 14, 2013), at http://www. corporatejustice.org/UPDATE-in-the-Nestle-Case.html.

98 ECCHR, Update in the Nestlé Case: Prosecutor Under Court Review, ECCHR Special Newsletter, May 17, 2013, at http://www.ecchr.de/index.php/ nestle-518.html.

99 http://www.justice.gov/archive/opa/pr/2007/March/07_nsd_161.html. 


\section{International law and civil liability}

Under international law private parties will bear obligations in respect of the crimes of universal jurisdiction. Criminal proceedings for breach of these obligations will be brought either through national courts or through international criminal tribunals. Although there have been no comparable institutions with power to award civil compensation for violations of the norms covered by the international criminal tribunals, the US courts have developed a jurisprudence on civil liability of individuals for violating norms of customary international law, either directly, or as aiders and abetters. The gateway for this development has been the Alien Tort Statute (ATS) 1789. The primary development in this area has been the voluminous litigation under the 1789 Statute since the revival of this dormant statute with the 1980 decision of the Second Circuit in Filartiga v. Pena-Irala. ${ }^{100}$ Since then, the federal courts of the US have been engaged on a judicial experiment in defining the contours of civil liability for violations of international law, although claims based on violations of customary international law have also been brought before the courts of Canada ${ }^{101}$ and of England.102 Customary international law has thereby come to have a horizontal effect on private parties by providing norms which give rise to a cause of action in national courts.

The development of universal civil jurisdiction as a means of closing the governance gap, which will be analysed in detail in Chapters 4 and 7 , has generated two controversies as to the nature of the civil liabilities imposed on private parties under customary international law. The first relates to the extra-territorial limits of universal civil jurisdiction. All ATS claims will have a foreign element - the plaintiff must be an alien. However, many ATS claims involve allegations of violations of international law occurring outside the US. Where the defendant is also an alien the result is that claims are being heard in US federal courts which have no connection with the US at all. These are so-called 'foreign

100 See generally, Filartiga v. Pena-Irala, 630 F.2d 876 (2nd Cir. 1980).

101 Bouzari v. Islamic Republic of Iran, [2002] OJ No 1624; [2004] OJ No 2800 Docket No. C38295, dismissed on grounds of sovereign immunity, and Bil'in (Village Council) v. Green Park Int'l Ltd, 2009 QCCS 4151, a claim alleging corporate complicity in war crimes in the occupied territories in Israel, dismissed on grounds of forum non conveniens.

102 Claims based on torture were brought in Al-Adsani v. Kuwait, 103 ILR 420 (QB 1995), aff'd Al-Adsani v. Kuwait, 107 ILR 536 (CA 1996) and Jones v. Saudi Arabia, [2006] UKHL 26; [2007] 1 AC 270 but were dismissed on grounds of sovereign immunity. 
cubed' suits which involve claims by a foreign plaintiff against a foreign defendant in respect of events that took place in a foreign jurisdiction. Concerns have been expressed by foreign States that the ATS has seen an exorbitant exercise of jurisdiction by US federal courts that violates the permissible limits on national jurisdiction under international law. ${ }^{103}$

In addressing this issue, a distinction has to be made between adjudicative and prescriptive jurisdiction. Adjudicative jurisdiction is where a court hears a dispute, such as a tort claim, involving matters that took place outside the jurisdiction, but does not apply its own rules of conduct. Prescriptive jurisdiction is where a court hearing such a dispute applies its own rules of conduct. As regards adjudicative jurisdiction, a cursory look at the jurisdictional rules of the courts of England and Wales will show that there is clearly no restriction on a State as to hearing civil claims that arise out of conduct outside the jurisdiction of the UK. Under the common law, English courts may assume jurisdiction over natural persons if a claim form has been properly served on them while in England, even if they are only temporarily present in England at the time. ${ }^{104}$ English courts may also assume jurisdiction over legal persons on the basis of service of proceedings in England. ${ }^{105}$ Claims with no connection with the UK are likely to be stayed on grounds of forum non conveniens where an alternative forum can be identified, although a stay will not be granted if to do so would cause substantial injustice to the

103 Kiobel v. Royal Dutch Petroleum Co. Brief of the Governments of the kingdom of the Netherlands and the United Kingdom of Great Britain and Northern Ireland as amici curiae in Support of Neither Party. N0 10-1491. June 13 2012. 2-3, 11-18.

104 See, e.g., Maharanee of Baroda v. Wildenstein, (1972) 2 QB 283 and Colt Indus. v. Sarlie, [1966] 1 WLR 440 (CA). The jurisdiction of the English courts over a defendant served within the jurisdiction in respect of events occurring outside the jurisdiction was established in Mostyn v. Fabrigas, (1775) 1 Cowper 161.

105 Service could be through CPR 6.9 which provides that service of proceedings on a foreign company may be made at 'any place in the jurisdiction where the corporation carries on its activities, or at any place of business of the company within the jurisdiction' or, as regards a company registered as an overseas company, pursuant to s 1139 Companies Act 2006. The dispute need not be connected with the defendant company's activities within the jurisdiction. Sea Assets v. PT Garuda Indonesia, (2000) 4 All ER 371, neither must the foreign company's activity constitute a substantial part of, or be incidental to, its main objects. South India Shipping Corp. v. Export-Import Bank of Korea, [1985] 1 WLR 585. 
claimant. ${ }^{106}$ There have been several instances where civil claims with no connection with England have been heard before the English courts such as Oppenheimer v. Louis Rosenthal \& Co. AG, 107 where leave was granted to serve a writ out of the jurisdiction because the Jewish plaintiff was unlikely to receive a fair hearing in proceeding in the courts of Nazi Germany, the more appropriate forum, and would risk being sent to a concentration camp were he to return to Germany.

Where a claim is made against a person domiciled in the UK, Article 2 of the Brussels Regulation requires the UK courts to accept jurisdiction, irrespective of where the conduct giving rise to the claim is situated. In this situation there is no possibility of a stay on grounds of forum non conveniens. ${ }^{108}$ English courts may also assume jurisdiction over a foreign defendant in a claim involving tortious acts abroad where a co-defendant is domiciled in England. ${ }^{109}$ Jurisdiction may also be assumed over a foreign defendant by agreement. ${ }^{110}$ Foreign tort claims which are 'foreign cubed' suits, therefore, are not a unique feature of the US legal order. A recent example of a 'foreign cubed' suit from outside the US is provided by the decision of the courts of the Netherlands, in Ashraf Ahmed El-Hojouj v. Harb Amer Derbal et al., in which damages were awarded against Libyan defendants in respect of torture of a Palestinian citizen in Libya. ${ }^{111}$

As regards prescriptive, or legislative, jurisdiction exercised by a State in relation to conduct taking place outside its territory, there are two views as to whether customary international law imposes any limits on such jurisdiction. The first view, based on the 1927 decision of the Permanent Court of International Justice in the Lotus case, is that a State

106 See, The Vishva Ajay, [1989] 2 Lloyd's Rep 558 (QB) a 'foreign cubed' case in which proceedings were brought in the High Court in relation to a collision between two vessels at a port in India when jurisdiction had been established by a sister-ship arrest.

107 [1937] 1 All ER 23.

108 Owusu v. Jackson, ECR I-1383.

109 See CPR PD 6B, s 3.1, and art 6(1) of the Brussels Regulation. On this basis jurisdiction was established in Motto \& Ors v. Trafigura, [2011] EWHC 90206, over the Dutch parent company of a UK company that had chartered a vessel from which toxic waste had been dumped in Africa leading to a negligence claim being brought before the English court.

110 As in Bodo Cmty., Claim No. HQ 11X01280, High Court (QB) where proceedings were originally issued against a UK parent company and its Nigerian subsidiary, and by agreement the claim then proceeded against the subsidiary alone in the English courts. The applicable law was that of Nigeria.

111 Hague District Court, No. 400882 (Mar. 21, 2012). 
is entitled to extend its prescriptive jurisdiction outside its territory, subject to any rules prohibiting such prescription in certain cases. ${ }^{112}$ The second, and more generally accepted view, is that international law imposes the requirement of a sufficiently close nexus to the forum asserting jurisdiction. ${ }^{113}$ That nexus may be demonstrated in the following ways. First, where the offender is a national of that State (the 'active personality' principle). Second, where the victim is a national of that State (the 'passive personality' principle). Third, and more controversially, where the extra-territorial conduct has adverse effects that are felt within the territory of the State. ${ }^{114}$ Fourth, in relation to crimes in respect of which there exists universal jurisdiction.

The position under customary international law with regard to a State's jurisdiction over extra-territorial conduct in civil cases is less clear. Some scholars deny that there are any restrictions on a State's jurisdiction ${ }^{115}$

1121927 PCIJ, Series A, No 10, 19.

113 Sir Robert Jennings and Sir Arthur Watts, eds, Oppenheim's International Law, § 138, 462 (9th ed. 1992); R Y Jennings, 'Extraterritorial Jurisdiction and the United States Antitrust Laws' (1957) 33 Brit YB Int'l L 146, 150-61; V. Lowe, 'Jurisdiction' in International Law (Malcolm D. Evans ed., 2nd ed., 2006), 342 ('The best view is that it is necessary for there to be some clear connecting factor, of a kind whose use is approved by international law, between the legislating state and the conduct that it seeks to regulate. The notion of the need for a linking point ... accords closely with the actual practice of states'); $\S 402(2)$ of the US Restatement (Third) of Foreign Relations; Blackmer v. United States, 284 US 421, 437 (1932). In The Nottebohm Case, (Liech. v. Guatamala), 1955 ICJ 4, 23 (Apr. 6) the ICJ stated that this well-established principle of jurisdiction requires 'a legal bond having as its basis a social fact of attachment, a genuine connection of existence, interests, and sentiments, together with the existence of reciprocal rights and duties' (emphasis added).

114 A doctrine asserted by the US where certain overseas activities had a substantial adverse effect within the US. See, e.g., Hartford Fire Ins Co v. Cal, 509 US 764, 796 (1993).

115 See eg, Michael Akehurst, 'Jurisdiction in International Law' (1975) 46 Brit Y B Int'l L 145, 177 (concluding that customary international law imposes no limits on civil jurisdiction) Gerald Fitzmaurice, 'The General Principles of International Law'(1957 II) 92 Recueil des Cours 1, 218; Peter Manczuk, Akehurst's Modern Introduction to Int'l Law (7th rev ed., 1997) 110. Malcolm Shaw International Law 652 (CUP, 8th ed., 2008) notes that the rarity of diplomatic protests has led some writers to conclude that customary international law does not prescribe any particular regulations to restrict courts' jurisdiction in civil matters. 
whereas others affirm that the restrictions on criminal proceedings apply equally to civil proceedings involving extra-territorial conduct. ${ }^{116}$

If there is a rule of customary international law governing the competence of States to entertain civil suits arising out of conduct committed outside the jurisdiction, what is its nature? If it mirrors the supposed rule relating to criminal suits, then claims involving domestic plaintiffs and defendants would be adjudicable under the 'passive' and 'active' nationality requirements respectively. But do the rules relating to civil suits acknowledge a further exception of universal jurisdiction? There is very little State practice on this question. What is clear is that universal jurisdiction in civil suits will not oust sovereign immunity ratione materiae as is the case with criminal cases. Torture claims against States and their agents were brought in Canada in Bouzari v. Islamic Republic of Iran, in Australia Zhang v. Zemin, ${ }^{117}$ and in the UK in $A l$ Adsani v. Govt of Kuwait ${ }^{118}$ and in Jones v. Govt of Saudi Arabia. ${ }^{119}$ All were dismissed on the grounds of sovereign immunity, notwithstanding that the claims arose out of violations of jus cogens norms of international law. The decision as to sovereign immunity in the two UK decisions was subsequently upheld by the European Court of Human Rights. ${ }^{120}$ In the US the Supreme Court has held that the ATS is pre-empted by the Foreign Sovereign Immunity Act 28 USC, section 1330, sections 1602-11. ${ }^{121}$ However, in both the US ${ }^{122}$ and Canada

116 See e.g., Ian Brownlie, Principles of Public International Law (6th ed., 2003) 298, arguing that there is no reason in principle to distinguish between the permissibility under international law of civil and criminal cases; Frederick A. Mann, 'The Doctrine of Jurisdiction in International Law' (1964 I) 111 Recueil Des Cours 1, 73-81, international law imposes substantial limits on civil jurisdiction; Frederick A. Mann,'The Doctrine of Jurisdiction Revisited After Twenty Years'(1984 III) 186 Recueil Des Cours 19, 20-33, 67-77.

117 [2010] 243 FLR 299.

118 (1995) 100 ILR 465, The Times 29 March 1996.

119 [2006] UKHL 26, [2006] 2 WLR 1424.

120 Al Adsani v. UK, (2002) 34 EHRR 11; Case of Jones and Others v. The United Kingdom (Applications nos. 34356/06 and 40528/06) Judgment 14 January 2014.

121 Argentine Republic v. Amerada Hess Shipping Corp, 488 US 428 (1989). In 1992 the Ninth Circuit held that this remained the position even where the claims were based on the violation of jus cogens norms, such as the prohibition on torture. Siderman de Blake v. Republic of Argentina, 965 F 2d 699 (9th Cir 1992).

122 USC s 1605A. 
legislation has been enacted to permit civil suits against States that are sponsors of terrorism. ${ }^{123}$

There is, therefore, no mandatory universal civil jurisdiction, but that does not mean that there is no permissive universal civil jurisdiction. In none of the cases referred to was it decided that extra-territorial civil jurisdiction was barred generally. Similarly in Jurisdictional Immunities of the State (Germany v. Italy) ${ }^{124}$ the ICJ held that Germany could rely on sovereign immunity to prevent its being held civilly liable in the Italian courts in respect of Nazi war crimes, but did not hold that there was a general bar on extra-territorial jurisdiction in civil cases. In any event, the recognition by any particular State of a cause of action deriving from a universal prohibition of international law applicable to non-State parties could not be said to be an exercise of prescriptive jurisdiction by that State as it would not involve the application of its own domestic law, but rather that of a universal norm of international law. The position under the ATS has now been resolved by the Supreme Court's decision in Kiobel v. Royal Dutch Petroleum Co that the statute had no extra-territorial application, based on the application of a US canon of statutory interpretation, a decision which has put an end to litigation of 'foreign cubed' cases under the ATS. ${ }^{125}$ However, Kiobel was not decided on the basis of any rule of international law precluding a State from asserting jurisdiction over 'foreign cubed' civil claims that have no connection with that State.

The second controversy is as to the type of persons subject to universal civil jurisdiction and whether legal persons can be regarded as subjects of customary international law. The contours of this nascent international civil law have been developed in the US federal courts by transplanting the principles under which international law imposes criminal liability on individuals into the field of civil liability in tort. However, from the Nuremberg and Tokyo tribunals to the ICC civil liability under customary international law is evidenced by the sources which established criminal liability, and the jurisdiction of every international criminal tribunal has been expressly limited to a jurisdiction over natural persons. Therefore, the argument goes, if universal civil jurisdiction derives from universal criminal jurisdiction it must follow that its effect is also limited to natural persons and that legal persons are subject to no obligations under customary international law. In September 2010 this reasoning led the

\footnotetext{
123 The Justice for Victims of Terrorism Act 2012.

124 Judgment, paras 91-97 (Feb. 3, 2012).

125133 S Ct 1659 (2013).
} 
Second Circuit in Kiobel v. Royal Dutch Petroleum Co to decide that suits under the ATS could not be brought against corporations. ${ }^{126}$

However, subsequent decisions in other Circuits have affirmed that corporations can incur liability under the ATS, reasoning that customary international law provides the prohibitive norms and it is then left to each State to determine how to apply them within their domestic legal order. Domestic law would then determine the issue of corporate liability. This is the approach taken by Judge Leval, dissenting, in Kiobel ${ }^{127}$ and by Judge Possner in Flomo v. Firestone Natural Rubber Co. ${ }^{128}$ Although it has never been possible to bring criminal proceedings against a corporation before an international tribunal, that does not necessarily mean that the prohibition against conduct is limited to natural persons. Volker Nehrlich has addressed this point as follows:

A norm of criminal law describing a crime may be understood as comprising two sub-norms: the first, most elementary, sub-norm consists of a prohibition of certain conduct, such as the prohibition to kill another person. To make it a norm of criminal law, however, a second sub-norm is required, which provides that the consequence of any contravention of the first sub-norm is criminal punishment. In international criminal law, this structure can best be observed in respect of war crimes, where the prohibition of certain conduct is generally contained in a rule of international humanitarian law, be it customary or conventional in nature; the second sub-norm is often grounded in international custom. ${ }^{129}$

Thus, international criminal proceedings against individuals evidences the prohibition of international law that binds all persons, natural or juridical, even though no international tribunals have been established with power to hear criminal cases against non-natural persons. This argument is supported by Judge Schwarz's analysis of the point in Presbyterian Church of Sudan v. Talisman Energy in which he noted that the IMT in the Farben and Krupp cases spoke of the corporations as having violated international law, even though the proceedings were against their individual executives. ${ }^{130}$ It is also echoed in the observations

126621 F 3d 111 (2d Cir 2010).

127 Ibid., 173-6.

128643 F 3d 1013, 1020-21 (7th Cir 2011)

129 Volker Nehrlich, 'Core Crimes and Transnational Business Corporations', 8 J. Int'l Crim. Just. 895, 898 (2010).

130244 F Supp. 2d 289, 315-6 (SDNY 2003).). At Nuremberg the heads of major German corporations were prosecuted for, inter alia, war crimes and crimes against humanity. In each of these cases, individuals, and not corporate entities, were put on trial, but the court consistently spoke in terms of corporate 
of Judge Shahabudeen in his separate opinion in Certain Phosphate Lands in Nauru:

In international law a right may well exist even in the absence of any juridical method of enforcing it ... Thus, whether there is a right to contribution does not necessarily depend on whether there exists a juridical method of enforcing contribution. ${ }^{131}$

This is an issue that can only be resolved by national courts when faced with a civil claim based on a violation of customary international law. In the US the issue is still unresolved and there remains a Circuit split. Although this question was referred to the US Supreme Court in Kiobel when the Supreme Court which gave judgment on 17 April 2013 it said nothing about this issue, instead deciding the claim on the basis of the territorial limits of the cause of action that could be created under federal common law pursuant to the grant of jurisdiction under the ATS.

liability. In United States v. Krauch, 8 Trials of War Criminals before the Nuremberg Military Tribunals under Control Council Law No. 10, 1081, 1140 (1952): it stated:

With reference to the charges in the present indictment concerning Farben's [a German corporation] activities in Poland, Norway, Alsace-Lorraine, and France, we find that the proof establishes beyond a reasonable doubt that offenses against property as defined in Control Council Law No. 10 were committed by Farben, and that these offenses were connected with, and an inextricable part of the German policy for occupied countries. [...]. The action of Farben and its representatives, under these circumstances, cannot be differentiated from acts of plunder or pillage committed by officers, soldiers, or public officials of the German Reich. [...] Such action on the part of Farben constituted a violation of the Hague Regulations [on the conduct of warfare] (emphases added).

Similarly in United States v. Krupp: '[T] he confiscation of the Austin plant [a tractor factory owned by the Rothschilds] [...] and its subsequent detention by the Krupp firm constitute a violation of Article 43 of the Hague Regulations [... and] the Krupp firm, through defendants[, ...] voluntarily and without duress participated in these violations.' 9 Trials of War Criminals Before the Nuernberg Military Tribunals Under Control Council Law No. 10 , 1327, 1352-53 (1950).

131 Certain Phosphate Lands in Nauru (Nauru v. Australia), Preliminary Objections, Judgment (sep. op. Shahabuddeen), ICJR (1992), 240, 290. 


\section{CORPORATE RIGHTS UNDER INTERNATIONAL LAW}

With the rise of globalisation corporations have obtained, under international law, extensive legal rights against States matching their economic power. ${ }^{132}$ Foreign investors have obtained these rights through the investor-state dispute settlement (ISDS) provisions of both bilateral investment treaties (BITs) and multilateral investment treaties between States. Since the 1990 s there has been a huge increase in the conclusion of BITs ${ }^{133}$ and multilateral trade and investment agreements such as the North American Free Trade Agreement, (NAFTA) between the US, Canada and Mexico, which came into force on 1 January 1994, the 2004 Central American Free Trade Agreement (CAFTA) ${ }^{134}$ and the 1994 Energy Charter Treaty (ECT). ${ }^{135}$ The EU is about to ratify the Comprehensive Economic and Trade Agreement (CETA) with Canada which contains ISDS provisions ${ }^{136}$ and is currently negotiating the Transatlantic

132 Business interests have also been indirect beneficiaries of the binding trade disciplines set up by the World Trade Organisation (WTO). Although the WTO agreements contemplate State-to-State arbitration, States have been quite willing to initiate proceedings to protect the interests of their corporations. Indeed, Philip Morris has funded various States, such as Ukraine, in bringing proceedings under the WTO against Australia in respect of its plain packaging law for cigarettes.

133 The first BIT was signed on 26 November 1959 between West Germany and Pakistan, coming into force on 28 November 1962. More than 2,000 of these BITs have now been concluded. The UK is currently party to 84 BITs, the US to 37.

134 The parties to the treaty are the US and Costa Rica, El Salvador, Guatemala, Honduras, Nicaragua, as well as the Dominican Republic, and entered into force for the US, El Salvador, Guatemala, Honduras, and Nicaragua in 2006, for the Dominican Republic in 2007, and for Costa Rica in 2009. The text of the treaty is available at https://ustr.gov/trade-agreements/free-tradeagreements/cafta-dr-dominican-republic-central-america-fta/final-text <accessed 8 April 2015>.

135 The ECT controls the transnational environment for trade, transfer and protection of investment in the energy sector. It entered into force in 1998, was signed by 51 states, including the EU and Euratom (Eastern and Western European states, the former Soviet Union, Japan, Australia). Part III, arts. 10-17 contain provisions for the protection of foreign investors in the energy sector.

136 Negotiations for CETA concluded in October 2013 with ratification due in 2015. However, in January 2015 France and Germany issued a joint declaration asking the European Commission to examine 'all the options for modifying' the ISDS clause in the agreement. 
Trade and Investment Partnership (TTIP) with the US which is also scheduled to contain ISDS provisions. ${ }^{137}$ On 13 January 2015 negotiations with the US on ISDS were suspended and will only resume once the Commission has come to the assessment that its new proposals guarantee among other things that the jurisdiction of courts in the EU Member States will not be limited by special regimes for investor-tostate-disputes. ${ }^{138}$ In the US on 22 April 2015, the Senate Finance Committee approved a bill to fast-track TTIP.

These investment treaties between States have privatised the international protection of investors by treaties giving investors of one party a direct right of action, through closed-door arbitration, against the government of the other country in the event of a violation of various provisions designed to protect investors, which extend beyond the prohibition on expropriation under international law. Common to nearly all these agreements are variants of the following provisions: 'national treatment' and 'most favoured nation treatment' provisions which extend the WTO disciplines on trade into the field of investment; provisions entitling the investor to fair and equitable treatment in accordance with international law; provisions entitling the investor to compensation in the event of expropriation or measures tantamount to expropriation.

Over the last 20 years corporations have woken up to the opportunities offered by these treaties to claim compensation from States when they are adversely affected by national and municipal laws, regulations, and even court decisions. Although investment treaties protect foreign investors, it has proved very easy for domestic investors to reorganise their corporate structure to turn themselves into foreign investors in advance of regulation that is likely to affect their business. A notable example is the ongoing arbitration brought by Philip Morris Asia (PMA) against Australia in connection with Australia's 2011 plain packaging laws for cigarettes. ${ }^{139}$ Having challenged the legislation in the Australian courts, and lost, PMA commenced arbitration under the Australia's BIT with

137 The Commission conducted a public consultation between 27 March and 13 July 2014. The Commission's summary of the responses received in the consultation is available at trade.ec.europa.eu/doclib/docs/2015/january/tradoc 153044.pdf <accessed 8 April 2015>.

138 http://europa.eu/rapid/press-release_MEMO-15-3202_en.htm <accessed 8 April 2015>.

139 A similar challenge is being made to Uruguay's tobacco packaging laws under Uruguay's BIT with Switzerland. A detailed legal analysis of the claims by Todd Weiler is available http://www.smoke-free.ca/eng_home/2010/PMIvs Uruguay/Opinion-PMI-Uruguay.pdf <accessed 16 April 2015>. 
Hong Kong. ${ }^{140}$ It was able to make use of this BIT by reorganising its corporate structure, through PMA acquiring a large number of shares in Philip Morris Ltd (Australia) shortly after the Australian government announced it was considering a plain packaging measure. ${ }^{141}$ Philip Morris is also funding various governments, such as Ukraine, in challenging Australia's measure in the WTO. ${ }^{142}$ Australia is vigorously resisting these challenges to its plain packaging measures.

Other noteworthy examples are: the arbitration initiated under the ECT by Swedish company Vattenfall challenging Germany's phase out of nuclear power following the Fukushima reactor disaster in 2011;143 the arbitration initiated under NAFTA against Canada by a Delaware Corporation, Lone Pine, challenging Quebec's moratorium on fracking: ${ }^{144}$ the arbitration initiated by a US corporation, Pacific Rim, under CAFTA against El Salvador in respect of its moratorium on gold mining; ${ }^{145}$ the arbitration initiated by Chevron against Ecuador in respect of a court judgment in Ecuador which awarded nearly $\$ 10$ billion against Chevron in compensation for oil pollution in the Amazon basin caused by a consortium in which Texaco, whose interest it acquired in 2001,

140 PMA claims that the measure constitutes an expropriation of its investments, is in breach of Australia's obligations to accord fair and equitable treatment to PMA's investments, that its investments have been deprived of fair and equitable treatment and that its investments have been deprived of full protection and security. Further details of the arbitration available at http:// www.ag.gov.au/tobaccoplainpackaging <accessed 16 April 2015>.

141 http://www.tobaccotactics.org/index.php/Australia:_Challenging_Legisla tion <accessed 16 April 2015>. In 2004 Australia concluded a free trade agreement with the US but public pressure entailed that the agreement did not include investor-state dispute settlement provisions.

142 For an informative, and humorous, analysis of the suit see https:// www.youtube.com/watch?v=6UsHHOCH4q8 <accessed 16 April 2015>.

143 For further details of the suit, see http://www.tni.org/briefing/nuclearphase-out-put-test <accessed 8 April 2015>. The claim is for $€ 1.4$ billion to cover lost profits.

144 For further details of the suit, see http://content.sierraclub.org/pressreleases/2013/10/lone-pine-resources-files-outrageous-nafta-lawsuit-againstfracking-ban <accessed 8 April 2015>. The claim is for US \$250 million to cover anticipated lost future profits.

145 For further details of the suit, see https://www.citizen.org/documents/ Pacific_Rim_Backgrounder1.pdf <accessed 8 April 2015>. The claim is for US $\$ 315$ million to cover anticipated lost future profits. 
was a participant. ${ }^{146}$ The Pacific Rim arbitration ${ }^{147}$ and the Lone Pine arbitration $^{148}$ involve Canadian-based businesses who have arranged their corporate structures so that there is a US corporation which is able to constitute the foreign investor which is able to bring suit under CAFTA and NAFTA respectively. ${ }^{149}$

The existence of bilateral investment treaties can contribute to the governance gap by providing a disincentive for host States to legislate to strengthen environmental and human rights standards. This is particularly the case where such agreements include 'stabilisation clauses', common in long-term investments in the extractive industries, which oblige the host State to freeze its existing regulatory structure for the length of the project, which may be for up to 50 years. In a report in 2008 Professor Ruggie drew attention to this in where he states:

To attract foreign investment, host States offer protection through bilateral investment treaties and host government agreements. They promise to treat investors fairly, equitably, and without discrimination, and to make no unilateral changes to investment conditions. But investor protections have expanded with little regard to States' duties to protect, skewing the balance between the two. Consequently, host States can find it difficult to strengthen domestic social and environmental standards, including those related to human rights, without fear of foreign investor challenge, which can take place under binding international arbitration. ${ }^{150}$

A subsequent study for Professor Ruggie and the International Finance Corporation noted:

146 See, further, discussion of the litigation in Chapter 2.

147 In December 2007, a subsidiary of Pacific Rim Mining Corp based in the Cayman Islands reincorporated in Nevada under the name Pac Rim Cayman LLC (Pac Rim) and this US subsidiary is the party bringing the suit under CAFTA, to which Canada is not a party.

148 The company bringing the suit has its headquarters in Calgary, but is incorporated in the US, so enabling it to proceed under NAFTA against Canada as a foreign investor. Until September of 2010, Lone Pine Resources had been a wholly owned subsidiary of a US company, Forest Oil Corporation. In September 2010, Lone Pine Resources became incorporated under the laws of the State of Delaware and after completion of an initial public offering on 1 June 2011 the company became a stand-alone corporate entity. In November 2012 the Delaware company commenced suit under NAFTA.

149 For further details of this strategy, see Richard G. Dearden and Wendy J. Wagner Bilateral Investment Treaty Considerations in Structuring Natural Resource Investments February 2013 http://www.gowlings.com/Knowledge Centre/article.asp?pubID=2776 <accessed 8 April 2015>.

150 A/HRC/8/5 7 April 2008 [34]. 
135. The results of this study suggest that investors and governments continue to conclude investment contracts in which they agree to exempt the investor from - or compensate the investor for the costs of - the application of new laws. Further, it is clear that in a number of cases the stabilization clauses are in fact drafted in a way that may allow the investor to avoid compliance with, or seek compensation for compliance with, laws designed to promote environmental, social, or human rights goals. Assuming the validity of using social and environmental laws as a surrogate for human rights, it is possible to infer further that some stabilization clauses in modern contracts may negatively impact the host state's implementation of its human rights obligations.

136. In the sample from this study, the stabilization clauses in non-OECD countries are more likely than those in OECD countries to limit the application of new social and environmental laws to the investments. ${ }^{151}$

The effect of BITs on State regulatory competence has led some States to give notice of withdrawal from their BITs. South Africa's Black Economic Empowerment policy gave rise to claims from investors in Luxembourg and Italy in 2007 claiming it amounted to an expropriation of their mineral rights. This has led to South Africa progressively terminating its BITs to avoid investor-state arbitration proceedings claiming compensation for economic expropriation. ${ }^{152}$ In 2013 it gave notice of termination of its BITs with the UK, the Netherlands, Belgium and Germany. In March 2014 Indonesia terminated its BIT with the Netherlands, the start of a process by which it will withdraw from all its BITs. However, many BITs contain 'survival clauses' which mean that for a period of ten to 15 years after termination their provisions will continue to apply to investments made while the treaty was in force.

151 Stabilization Clauses and Human Rights. A research project conducted for IFC and the United Nations Special Representative of the Secretary-General on Business and Human Rights 27 May 2009.

152 Such a claim was brought in 2007 by investors from Luxembourg and Italy, arguing that South Africa's Mining and Petroleum Resources Development Act (MPRDA) contained provisions that expropriated their mineral rights. http://hsfnotes.com / arbitration/2013/08/21/south-africa-terminates-its-bilateralinvestment-treaty-with-spain-second-bit-terminated-as-part-of-south-africas-plannedreview-of-its-investment-treaties/ <accessed 7 March 2015>. See, too, https:// www.dlapiper.com/en/uk/insights/publications/2014/12/international-arbitrationnewsletter-q4-2014/challenging-the-status-quo/ <accessed 14 April 2015>. 